\title{
Basement Structure and Styles of Active Tectonic Deformation in Central Interior Alaska
}

\author{
Nilesh C. Dixit ${ }^{1, *}$ and Catherine Hanks ${ }^{2}$
}

1 Department of Physics, Geology and Engineering Technology, Northern Kentucky University, Nunn Drive, Highland Heights, KY 41099, USA

2 Department of Geosciences, University of Alaska Fairbanks, 900 Yukon Drive, Fairbanks, AK 99775, USA; clhanks@alaska.edu

* Correspondence: dixitn1@nku.edu

Citation: Dixit, N.C.; Hanks, C. Basement Structure and Styles of Active Tectonic Deformation in Central Interior Alaska. Geosciences 2021, 11, 127. https://doi.org/ 10.3390/geosciences 11030127

Academic Editors:

Jesus Martinez-Frias and Lev

V. Eppelbaum

Received: 15 January 2021

Accepted: 24 February 2021

Published: 10 March 2021

Publisher's Note: MDPI stays neutral with regard to jurisdictional claims in published maps and institutional affiliations.

Copyright: (C) 2021 by the authors. Licensee MDPI, Basel, Switzerland. This article is an open access article distributed under the terms and conditions of the Creative Commons Attribution (CC BY) license (https:// creativecommons.org/licenses/by/ $4.0 /)$.

\begin{abstract}
Central Interior Alaska is one of the most seismically active regions in North America, exhibiting a high concentration of intraplate earthquakes approximately $700 \mathrm{~km}$ away from the southern Alaska subduction zone. Seismological evidence suggests that intraplate seismicity in the region is not uniformly distributed, but concentrated in several discrete seismic zones, including the Nenana basin and the adjacent Tanana basin. Although the location and magnitude of the seismic activity in both basins are well defined by a network of seismic stations in the region, the tectonic controls on these intraplate earthquakes and the heterogeneous nature of Alaska's continental interior remain poorly understood. We investigated the crustal structure of the Nenana and Tanana basins using available seismic reflection, aeromagnetic and gravity anomaly data, supplemented by geophysical well logs and outcrop data. We developed nine new two-dimensional forward models to delineate internal geometries and the crustal structure of Alaska's interior. The results of our study demonstrates a strong crustal heterogeneity beneath both basins. The Tanana basin is a relatively shallow (up to $2 \mathrm{~km}$ ) asymmetrical foreland basin with its southern, deeper side controlled by the northern foothills of the Central Alaska Range. Northeast-trending left lateral strike-slip faults within the Tanana basin are interpreted as a zone of clockwise crustal block rotation. The Nenana basin has a fundamentally different geometry. It is a deep (up to $8 \mathrm{~km}$ ), narrow transtensional pull-apart basin that is deforming along the left-lateral Minto Fault. This study identifies two distinct modes of current tectonic deformation in Central Interior Alaska and provides a basis for modeling the interplay between intraplate stress fields and major structural features that potentially influence the generation of intraplate earthquakes in the region.
\end{abstract}

Keywords: potential field modeling; interior Alaska; transtensional basin; foreland basin; seismic interpretation

\section{Introduction}

The observed occurrence of intraplate earthquakes within a rigid continental interior provides direct evidence of localized zones of high strain concentration hundreds of kilometers away from the plate boundary. Although such events account for less than 10 percent of all global earthquakes and release only 5 percent of the global seismic energy, they can inflict heavy damage to human lives and property in the region [1]. From a plate tectonics view, intraplate earthquakes provide important information about the rheology of the lithosphere and tectonic forces and stresses operating within the lithosphere [2,3]. Investigating relationships among lithospheric strength, tectonic stresses, and intraplate seismicity can significantly improve our knowledge of intraplate dynamics, which would allow us to accurately perform seismic hazard assessment in an intraplate setting.

Central Interior Alaska is one of the most seismically active intraplate regions in the North America. In the past, this region has experienced significant seismic activity, including large-scale earthquakes as high as Mw 7.9. Examples include 2002 Mw 7.9 Denali 
Fault earthquake; 1967 Mw 5-6 Fairbanks earthquake; 1937 Mw 7.3 Salcha earthquake; 1947 Mw 7.2 earthquake in the northern foothills of the Alaska Range [4-6] (Figure 1). Based on increasing seismological evidence, intraplate seismicity in the Central Alaska region appears to not be uniformly distributed, but concentrated in several discrete seismic zones (Figure 1). The location and magnitude of the seismic activity in Central Alaska is well defined by a network of seismic stations in the region. However, the tectonic controls on intraplate earthquakes and the heterogeneous nature of the continental lithosphere remain poorly understood. A detailed knowledge of the crustal structure beneath Central Alaska province is critical to help test various tectonic models explaining the interplay between the intraplate stress fields causing earthquakes and the development of regional structural features in this region.

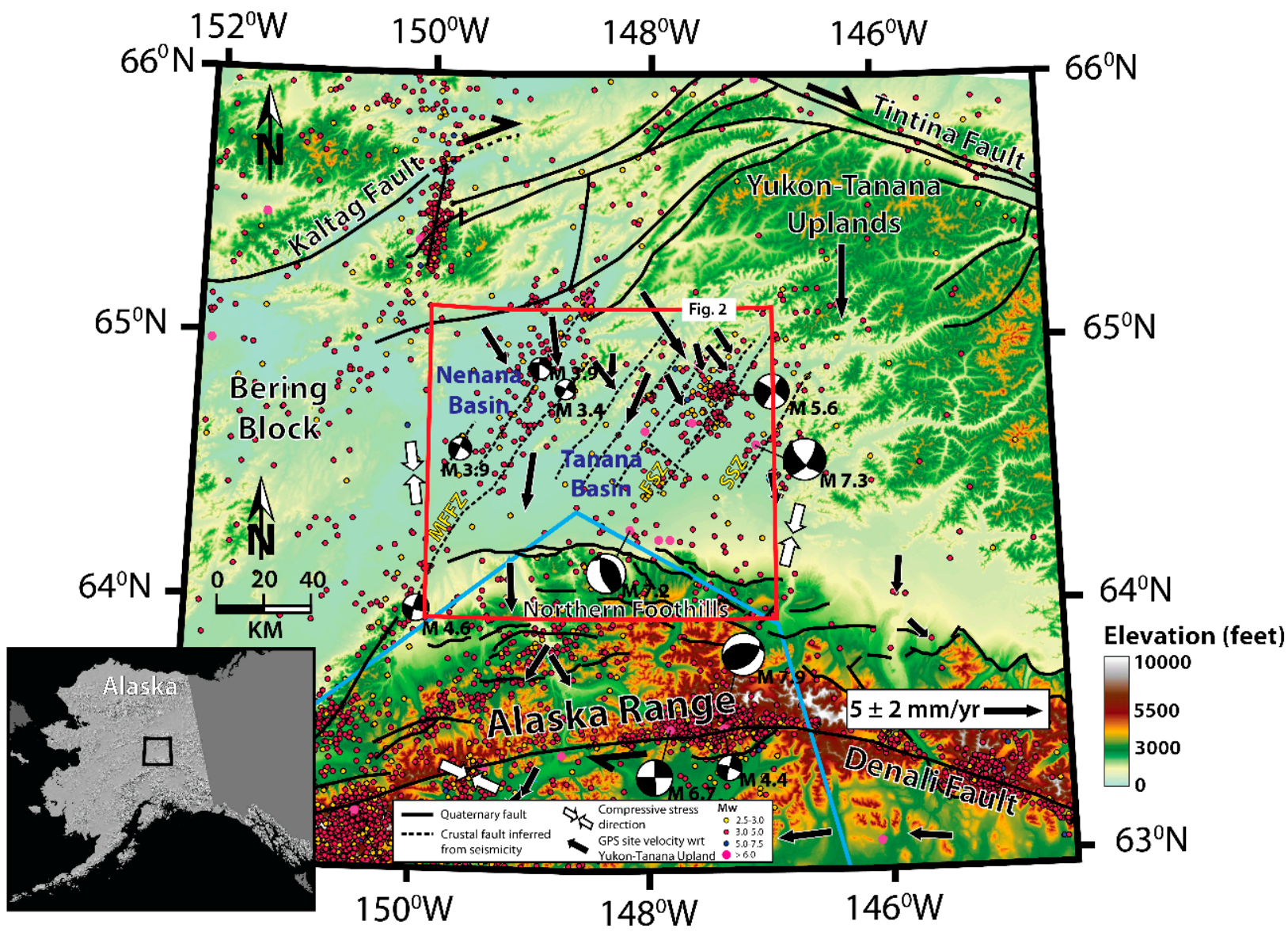

Figure 1. Simplified tectonic map of central Alaska showing the location of the study area relative to major active tectonic features and the major active faults in the region [7-10]. Red box indicates the position of Figure 2. The Minto Flats Seismic Zone (MFSZ), the Fairbanks Seismic Zone (FSZ), and the Salcha Seismic Zone (SSZ). The horizontal velocity vectors are measured relative to the stable North American craton and are inferred from the GPS velocities calculated for the region by Fletcher [5]. Focal mechanism solutions of notable earthquakes in interior Alaska indicate N-S directed compressive stresses in response to the plate subduction along the southern margin of Alaska [4,6,11]. The blue solid line marks the flat-slab region showing the subducted extent of the Yakutat microplate [6].

In this study, integrated geophysical investigations were carried out to image the subsurface structures, basement depth, and formation boundaries to construct new crustal scale models for the Central Alaska province. The structure of the upper crust was defined by integrating gravity and magnetic field data with newly obtained industry seismic reflection profiles, geophysical logs, and outcrop data. The models presented in this paper help to constrain the basin geometries, define major boundaries between the sedimentary and underlying heterogeneous basement units, identify the possible location of intrusive 
bodies, and identify possible active geologic structures responsible for the ongoing crustal deformation in the region. Our results show that the Cenozoic sedimentary basins that form the upper crust of Central Alaska differ significantly in their age, basement structure and style of tectonic deformation. The findings from this research provide new information on the role of active fault systems as well as the structural features in creating a widespread intraplate deformation zone in Central Alaska that exist hundreds of kilometers away from the nearest plate boundary.

\section{Tectonic Framework of Central Interior Alaska}

Central Alaska is mainly underlain by several Precambrian, Paleozoic to lower Mesozoic age sequences of metamorphic and igneous rocks belonging to parautochthonous to allochthonous terranes that were accreted to North America by the Early to Late Cretaceous [12,13]. These accreted rocks were subsequently and intensely disrupted and deformed by later tectonic events, producing a complex pattern of sedimentary basins and uplands around the basins. Three major regional structural features control the neotectonics of central Alaska (Figure 1). From north to south, these are the Kaltag-Tintina Fault system, the Alaska Range fold-and-thrust belt, and the Denali Fault system. The Tintina Fault is a steeply dipping dextral strike-slip fault that extends through central Alaska and separates deformed North American crustal rocks in the north from the accreted Yukon-Tanana Composite Terrane rocks of Interior Alaska [14]. The Alaska Range is a dextral transpressional orogen with north-vergent thrusting along the northern foothills fold-and-thrust belt and strike-slip faulting along the Denali Fault [15,16]. The Denali Fault is an active intraplate, dextral strike-slip fault that arcs through the Alaska Range and accommodates dextral shear strain resulting from the oblique plate convergence to the south $[17,18]$. At present, the shallow oblique subduction and collision of the Yakutat microplate along the southern Alaska margin drives the dextral transpressional deformation across the Alaska Range (Figure 1). The Denali Fault is an active intraplate, dextral strike-slip fault that arcs through the Alaska Range and accommodates dextral shear strain resulting from the oblique plate convergence to the south $[17,18]$.

Seismicity in the vicinity of the Fairbanks area exhibits a series of northeast-trending seismic zones with left-lateral strike-slip fault plate solutions (the Minto Flats seismic zoneMFSZ, the Fairbanks seismic zone-FSZ and Salcha seismic zone-SSZ) [4] (Figure 1). To the south of the MFSZ, the Kantishna seismic zone is another notable high seismicity zone, characterized by strike-slip focal plane solutions [1]. In contrast, earthquakes with thrust fault plane solutions predominate the seismicity within the Alaska Range fold-and-thrust belt region [2].

Some researchers believe that the pattern of intraplate seismicity observed in Central Alaska reflects a pure shear zone that exists between the Denali and Tintina Fault systems, driven primarily by north-south directed crustal shortening in response to oblique plate convergence beneath the southern Alaska margin [16,19].

\section{Interior Basins}

Beginning in early Cenozoic time, tectonic deformation in Central Alaska produced several basins, the Nenana and Tanana basins that share similar sedimentary sequences. These Cenozoic basins of Central Alaska are located between the Denali and Tintina Fault systems and to the north of the Central Alaska Range (Figure 1). Topographically, the basins are expressed as the low-lying swampy area of about $23,500 \mathrm{~km}^{2}$ south and west of the Yukon-Tanana Upland. Based on gravity and seismic reflection data, the Nenana basin has been interpreted as an extensional half-graben associated with high-angle normal faulting across the Minto Fault [20-22]. However, recent crustal seismicity studies of Interior Alaska have suggested that the Nenana basin is bounded by two major active northeast-striking sinistral strike-slip faults [19] (Figure 1). These basin-bounding faults form a seismic zone that is interpreted as the eastern edge of a diffuse plate boundary between the Bering plate to the west and North American plate to the east [23]. In contrast, 
the Tanana basin, immediately east of the Nenana basin, is a Neogene transpressional foreland basin actively forming and deforming in response to regional transpressional deformation in south-central Alaska [24,25]. Ridgway and all [26] suggested that the southern part of the Tanana basin is actively deforming due to flexural subsidence related to northward propagation of the Neogene fold-and-thrust belt of the Central Alaska Range. In their interpretation, the Pliocene Nenana gravel was deposited in a proximal foredeep along the northern edge of the thrust front.

Both of Nenana and Tanana basins largely contain Tertiary non-marine sedimentary strata deposited uncomfortably on Proterozoic to Late Paleozoic basement schist rocks of the Yukon-Tanana Composite Terrane [22,26] (Figure 2 and Table 1). The Tertiary sedimentary strata include (1) Late Paleocene formation (mainly present in the Nenana basin), (2) Miocene Usibelli Group, (3) Pliocene Nenana gravel and (4) quaternary surficial and unconsolidated deposits. The Usibelli Group is further subdivided into five formations: the Healy Creek, Sanctuary, Suntrana, Lignite Creek and Grubstake formations [27].

Table 1. Generalized stratigraphy and associated rock properties for units in the Nenana and Tanana basins and adjacent exposed rocks. Rock formations are color-coded and presented in geologic cross-sections.

\begin{tabular}{|c|c|c|c|c|c|c|}
\hline Period/Epoch & Formation & Major Lithology & $\begin{array}{l}\text { Depositional } \\
\text { Environment }\end{array}$ & $\begin{array}{l}\text { Assigned Density } \\
\left(\mathrm{kg} / \mathrm{m}^{3}\right)\end{array}$ & $\begin{array}{c}\text { Assigned } \\
\text { Susceptibility } \\
\left(\mathrm{SI} \times 10^{-3}\right)\end{array}$ & Color Code \\
\hline Quaternary & Surficial Deposits & $\begin{array}{l}\text { Unconsolidated gravel, } \\
\text { sand, silt and clay }\end{array}$ & $\begin{array}{c}\text { Alluvial } \\
\text { fan/flood-plain/ } \\
\text { lacustrine/swamp }\end{array}$ & $1800-1900$ & 0.02 & \\
\hline Pliocene to Miocene & Nenana Gravel & $\begin{array}{c}\text { Coarse-grained } \\
\text { conglomerate and } \\
\text { sandstone } \\
\end{array}$ & $\begin{array}{c}\text { Alluvial } \\
\text { fan/braided fluvial } \\
\text { systems }\end{array}$ & $2100-2250$ & 0.22 & \\
\hline \multirow{5}{*}{$\begin{array}{l}\text { Miocene to Late } \\
\text { Eocene }\end{array}$} & $\begin{array}{l}\text { Grubstake } \\
\text { Formation }\end{array}$ & $\begin{array}{l}\text { Laminated mudstone and } \\
\text { sandstone }\end{array}$ & Lacustrine & \multirow{5}{*}{$2300-2450$} & \multirow{5}{*}{0.25} & \\
\hline & $\begin{array}{l}\text { Lignite Creek } \\
\text { Formation }\end{array}$ & $\begin{array}{l}\text { Conglomerate, sandstone, } \\
\text { mudstone and coal }\end{array}$ & $\begin{array}{c}\text { High-sinuosity } \\
\text { mixed-load fluvial } \\
\text { systems }\end{array}$ & & & \\
\hline & Suntrana Formation & $\begin{array}{l}\text { Coarse grained sandstone } \\
\text { and coal }\end{array}$ & $\begin{array}{c}\text { Distal sandy } \\
\text { braided fluvial } \\
\text { systems }\end{array}$ & & & \\
\hline & $\begin{array}{l}\text { Sanctuary } \\
\text { Formation }\end{array}$ & Laminated mudstone & Lacustrine & & & \\
\hline & $\begin{array}{l}\text { Healy Creek } \\
\text { Formation }\end{array}$ & $\begin{array}{l}\text { Conglomerate, sandstone, } \\
\text { mudstone and coal }\end{array}$ & $\begin{array}{c}\text { Proximal, gravelly } \\
\text { braided stream } \\
\text { systems } \\
\end{array}$ & & & \\
\hline $\begin{array}{l}\text { Early Eocene to } \\
\text { Late Paleocene }\end{array}$ & $\begin{array}{l}\text { Late Paleocene } \\
\text { Sediments }\end{array}$ & $\begin{array}{c}\text { Siltstone, mudstone } \\
\text { and coal }\end{array}$ & $\begin{array}{l}\text { Fluvial/lacustrine/ } \\
\text { swamp/alluvial fan }\end{array}$ & $2450-2500$ & 0.29 & \\
\hline $\begin{array}{l}\text { Early Mississippian } \\
\text { to Middle Devonian }\end{array}$ & Totatlanika schist & $\begin{array}{l}\text { Metavolcanic and } \\
\text { metavolcaniclastic } \\
\text { quartzfeldspathic schist, } \\
\text { phyllite and gneiss; } \\
\text { metamorphic grade } \\
\text { varying locally between } \\
\text { greenschist, amphibolite } \\
\text { and gneissic facies gneiss } \\
\text { with phyllite }\end{array}$ & 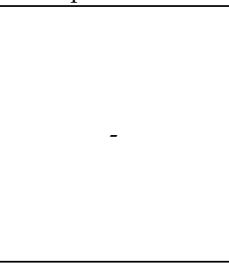 & $2550-2620$ & 0.4 & \\
\hline $\begin{array}{l}\text { Early Paleozoic to } \\
\text { Proterozoic }\end{array}$ & $\begin{array}{l}\text { Yukon-Tanana } \\
\text { schists }\end{array}$ & $\begin{array}{l}\text { Quartz-mica (pelitic } \\
\text { schist) and phyllite, } \\
\text { locally calcareous and } \\
\text { carbonaceous. Dominant } \\
\text { metamorphic grade } \\
\text { greenschist facies, varies } \\
\text { across high-angle faults in } \\
\text { Yukon-Tanana Upland to } \\
\text { as high as eclogite facies }\end{array}$ & - & $2650-2750$ & 0.5 & \\
\hline $\begin{array}{l}\text { Paleocene to Late } \\
\text { Cretaceous }\end{array}$ & Intrusions & $\begin{array}{c}\text { Plutons and dikes } \\
\text { composed of granodiorite, } \\
\text { tonalite, diorite, } \\
\text { monzonite, syenite } \\
\text { and gabbro }\end{array}$ & - & $2620-2900$ & 3 to 30 & $\bullet \bullet \bullet \bullet \bullet \bullet \bullet \bullet$ \\
\hline
\end{tabular}

Only four exploration wells have been drilled in Cenozoic non-marine rocks of the Nenana basin, and no deep well has been drilled into the Tanana basin (Figure 2). Although the geology and structures along the northern and southern margins of the Nenana and Tanana basins have been studied extensively in the past, the present-day crustal structure 
and internal geometries of both basins are poorly understood. In addition, published information on the basement structure of the Nenana and Tanana basins is sparse. This region, especially the Nenana basin, is still considered a largely underexplored "frontier" area for hydrocarbon exploration and many gaps remain in our understanding of the extent of sedimentary sequences and present-day deformation style of the region.

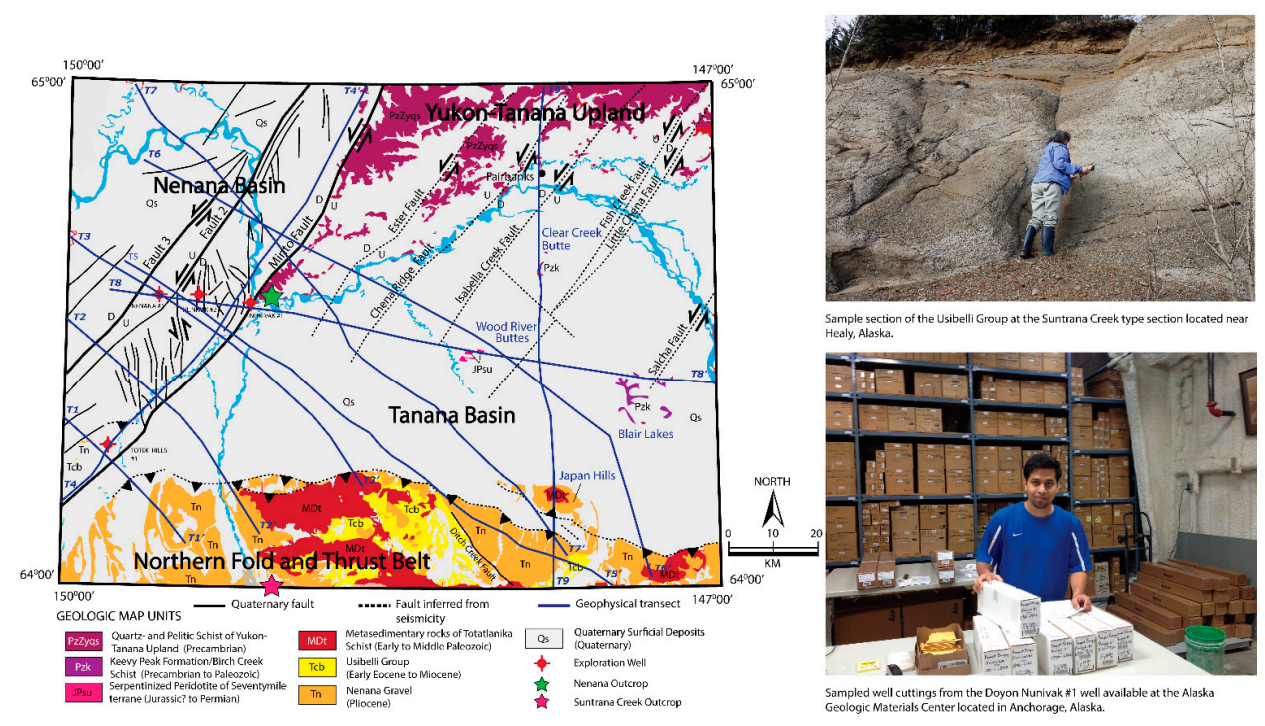

Figure 2. Geologic map of central Alaska, showing the Cenozoic-age Nenana and Tanana basins and exposed geology, including major lithologic units and regional fault systems. The present-day active faults are inferred from the available surface outcrops and active seismicity in the region [7-10]. Quaternary thrust faults (black solid line with thrust symbols) define the northern limit of the northern foothills in the fold-and-thrust belt of the Central Alaska Range [7]. Solid blue lines indicate the locations of profiles for the potential field models developed in this study. Geologic map modified from Wilson and all [28]. We collected 107 rock outcrop samples at the Suntrana Creek outcrop to measure the bulk densities and magnetic susceptibilities of rocks (inset on top-right). In addition to outcrop samples, we sampled 133 drill cuttings from the Nunivak-1 well at the Alaska Geological Materials Center (inset on bottom-right). Rock densities and susceptibilities are published by Dixit and Tomsich [29].

\section{Methodology}

In this study, integrated geophysical investigations were carried out to image the subsurface structures, basement depth and formation boundaries to construct new crustal scale models for the Central Alaska province. The structure of the upper crust was defined by integrating gravity and magnetic field data with newly acquired industry seismic reflection profiles, geophysical logs and outcrop data.

\subsection{Physical Rock Properties}

Gravity and magnetic anomalies observed at the surface are caused by lateral variations in bulk densities and magnetic susceptibilities of the underlying lithologic units [30-32] To model the gravity and magnetic anomalies, we analyzed outcropping rock samples and drill cuttings from the exploration wells to obtain the rock bulk densities and their magnetic susceptibilities. The physical property data collected from these rock samples were then used to constrain our potential field models of the region. Table 1 summarizes observed and averaged magnetic susceptibility and rock density values for all modeled lithologic units in our study area.

We measured 107 rock outcrop samples of sedimentary and metamorphic rocks exposed along the George Parks Highway, near the Nenana town and at the type section in the Suntrana Creek area (Figure 2). A portable, magnetic susceptibility meter Terraplus K-10 with resolution of $1 \times 10^{-6}$ SI unit was used for the magnetic susceptibility measurements. The bulk density measurements of outcrop samples were performed in the laboratory at 
the University of Alaska Fairbanks by calculating the total mass and volume for every sample. In addition to outcrop samples, we sampled 133 drill cuttings from Nunivak 1 well at the Alaska Geologic Materials Center (GMC) to measure their magnetic susceptibilities and bulk densities [29] (Figure 2). For drill cuttings, we used Bartington MS2 magnetic susceptibility meter (Fairbanks, AL, USA) with resolution of $2 \times 10^{-6}$ SI unit to calculate magnetic susceptibilities.

\subsection{Seismic and Well Log Interpretation}

For our study, we performed an integrated analysis of well logs from four exploration wells and seismic reflection data (courtesy of ConocoPhillips (Anchorage, AL, USA)) available for the southern part of the Nenana basin (Figures 3-6). The seismic data include four two-dimensional (2D), time-migrated seismic profiles (TA02, TA03, TA04 and TA05) that extend down to $4 \mathrm{~s}$ in two-way-travel times (T.W.T.), corresponding to approximately $5.5 \mathrm{~km}$ of depth in the subsurface (Figures 5 and 6). We tied publicly available digital well data with ConocoPhillips's 2D seismic reflection profiles using synthetic seismograms generated in the IHS Kingdom Suite version 8.8. The depth-converted seismic horizons, constrained by well data, were used to generate structural and sediment thickness maps for our study area. In addition to ConocoPhillips's seismic data, Doyon Limited (Fairbanks, AL, USA) (2015) published a series of seismic reflection profiles acquired in the Nenana basin for oil gas exploration purpose. We integrated Doyon Limited's more recent published seismic data with the 2D seismic grid provided by ConocoPhillips to provide a full structural framework for the entire Nenana basin (Figure 5) (Accessed on 25 August 2016). The resulting, well-constrained seismic interpretation for the Nenana basin was then used to augment our potential field models for the basin

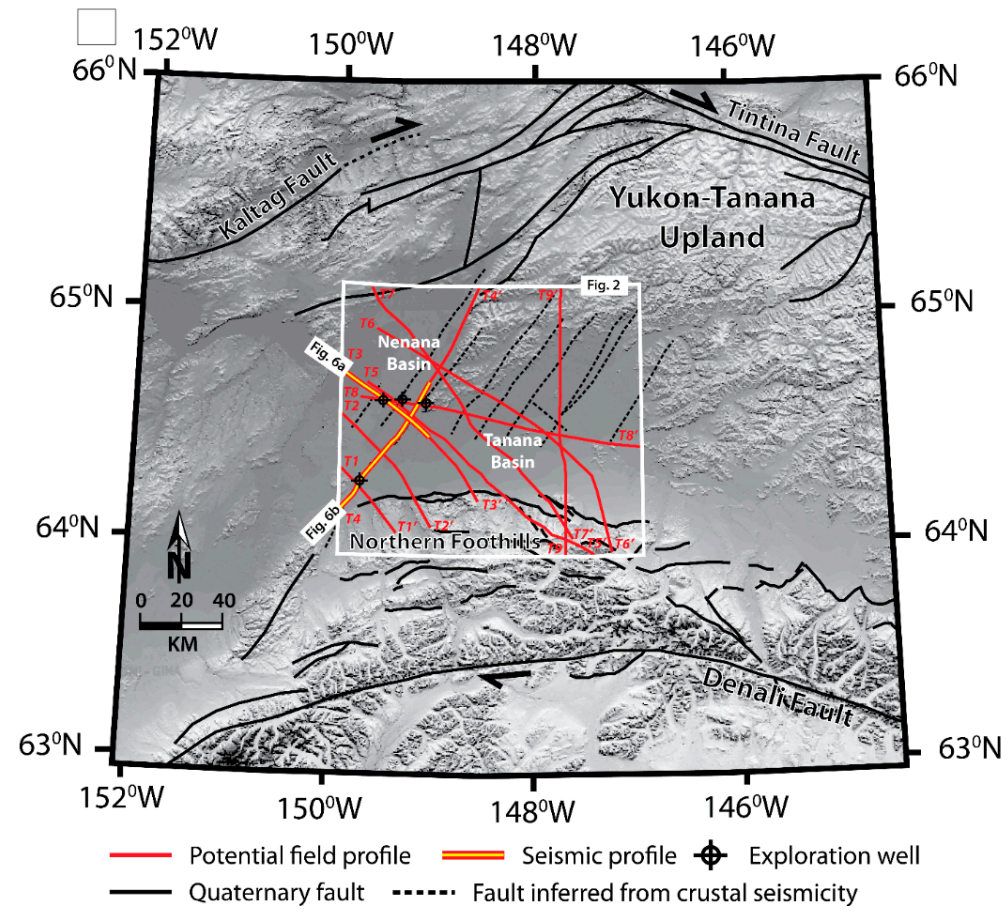

Figure 3. Location of the presented geophysical transects relative to the major structural features of central Alaska. Four profiles (T1 to T4) entirely lie within the southern part of the Nenana basin and coincide with 2D seismic profiles (courtesy of ConocoPhillips). The northwestern segments of four additional profiles (T5 to T8) extend from the northwestern margin of the northern Nenana basin to the eastern and southern margin of the Tanana basin and transect the inferred geologic boundary between the two basins. Profile T9 is a south-to-north profile that starts at the northern foothills of the Central Alaska Range, extending northward across the basin, and ends in the Yukon-Tanana Upland, north of the Tanana basin. 


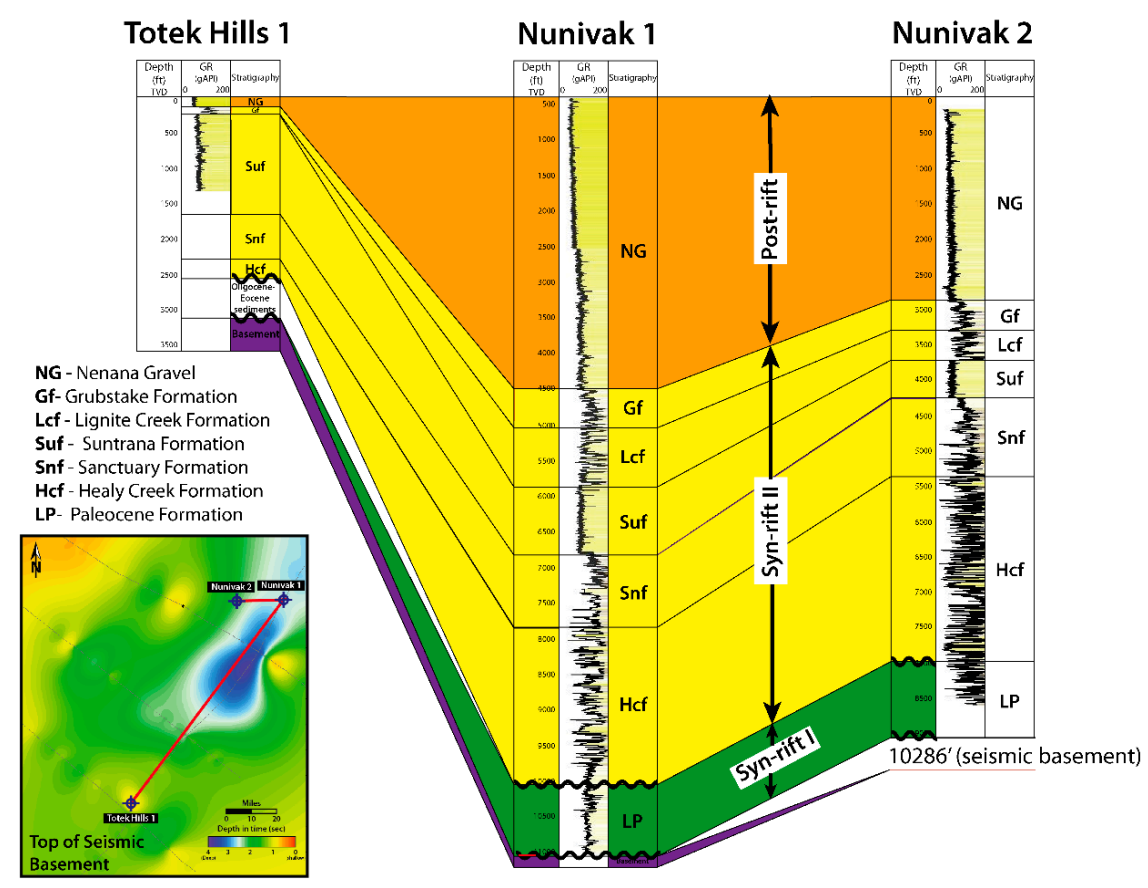

Figure 4. Lithostratigraphic correlation of exploration wells showing the subsurface depths and thickness variations of sedimentary sequences in the southern part of the Nenana basin [19,29,33]. Formation ages are based on palynomorphs data (G. Van Kooten, written communication, 2016).
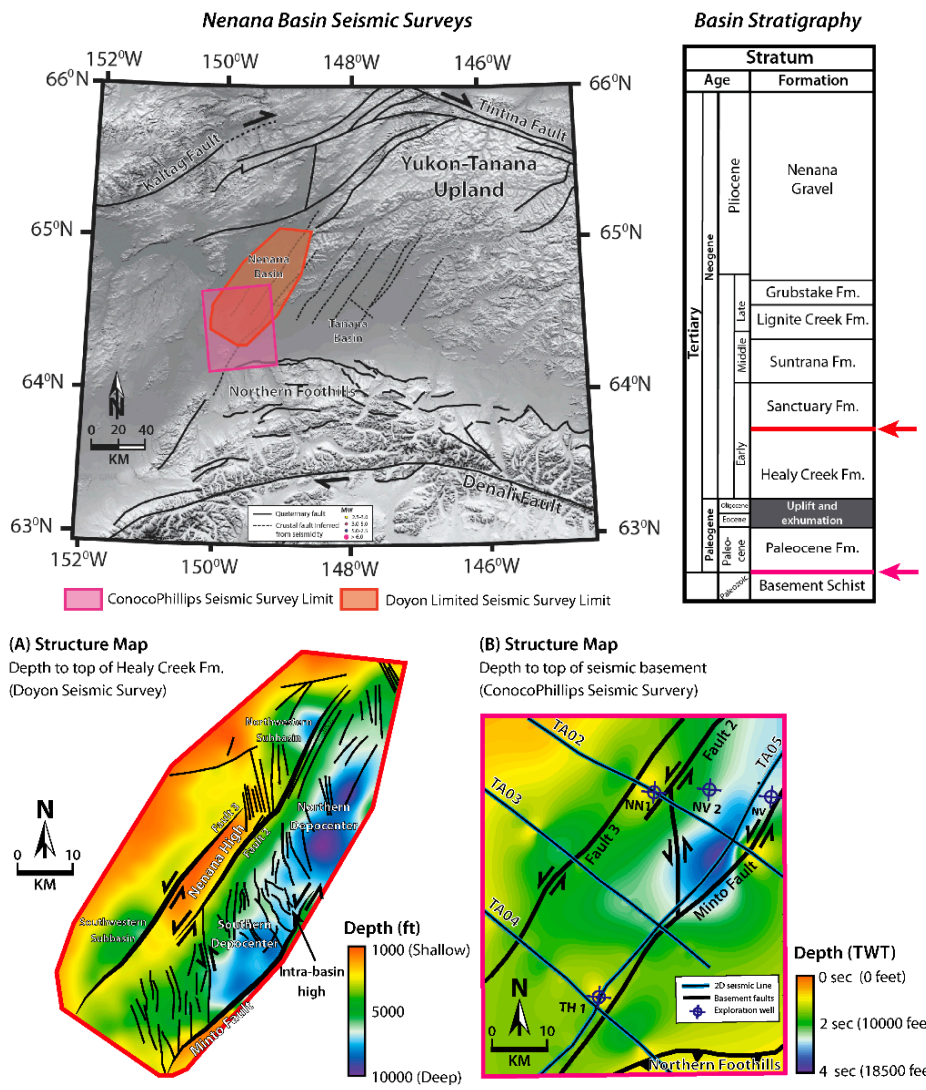

(B) Structure Map

Depth to top of seismic basement

(ConocoPhillips Seismic Survery)

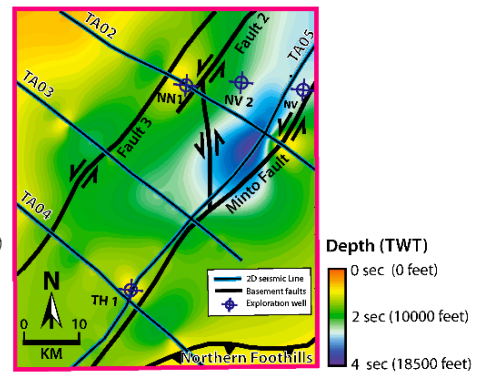

Figure 5. Location and extent of seismic reflection surveys used to investigate the subsurface geometry of rock sequences and the orientations of major faults in the Nenana basin. The red polygon (A) represents the extent of seismic reflection profiles acquired and published by Doyon Limited (2015). The pink polygon depicts the boundary of the two-dimensional seismic survey (B) acquired and provided for our study by ConocoPhillips. 
Seismic profile TA-02

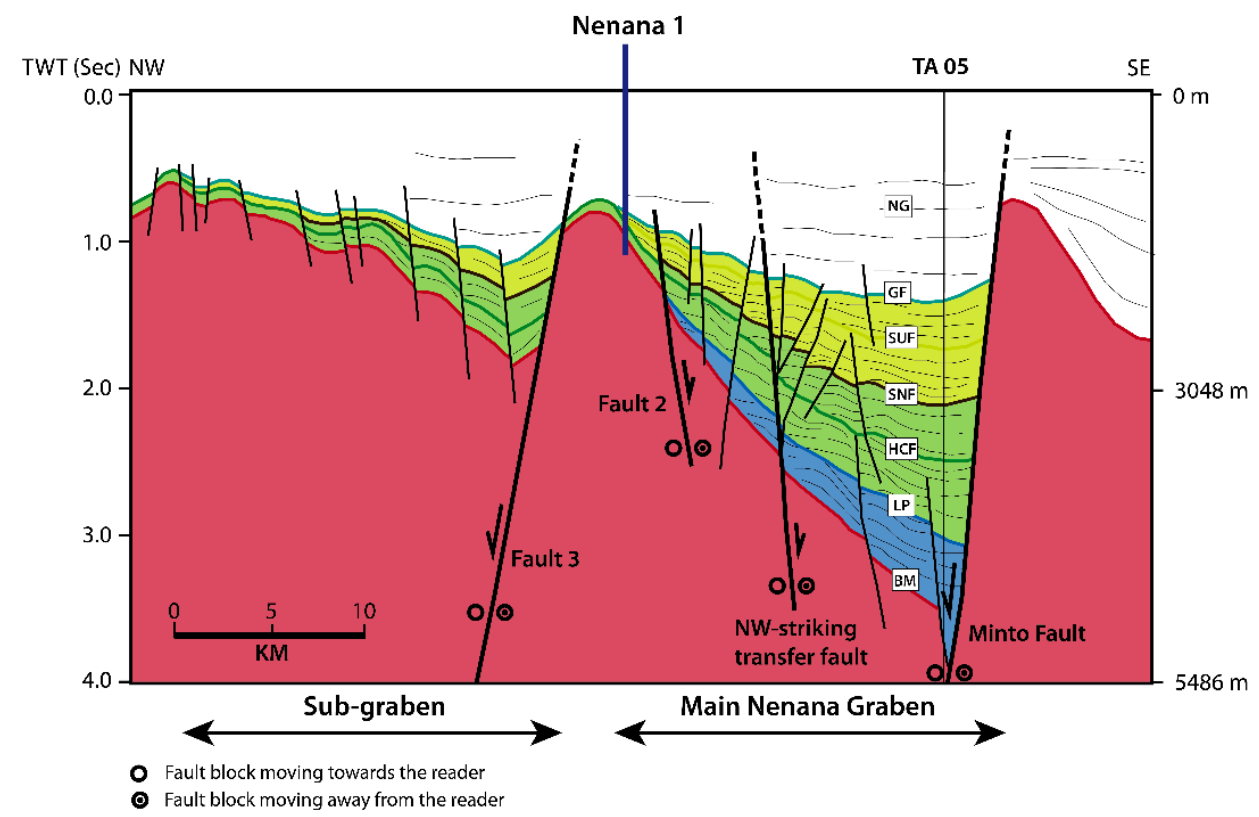

(A)

Seismic profile TA-05

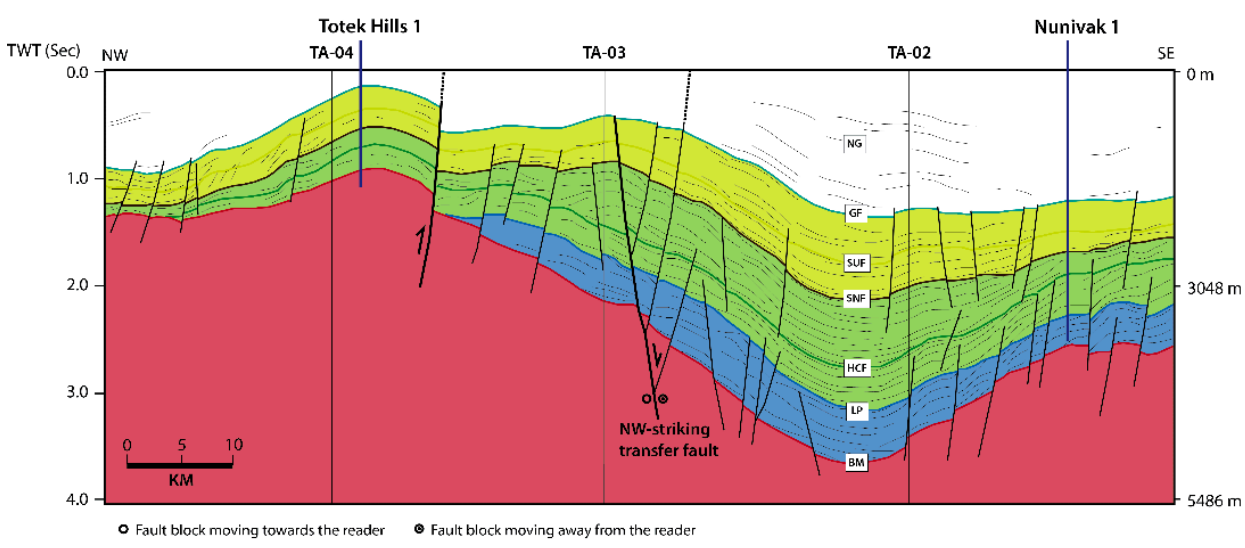

(B)

Figure 6. (A) Structural interpretation of seismic profile TA-02 across the Nenana basin. (B) Structural interpretation of seismic profile TA-05 along the Nenana basin. See Figure 5 for the location of seismic profiles TA-02 and TA-05. BMbasement; LP-Paleocene formation; HCF-Healy Creek formation; SNF-Sanctuary formation; SUF-Suntrana formation; GF-Grubstake formation; NG-Nenana gravel.

No seismic reflection data are available for the Tanana basin. However, several regional geophysical transects incorporating deep seismic refraction, teleseismic and gravity data provide valuable constraints on the crustal structure of the Tanana basin $[6,31,34,35]$.

\subsection{Potential Field Data}

\subsubsection{Gravity Anomaly Data}

To perform 2D forward modeling of gravity data, we used a high-resolution regional complete Bouguer anomaly (CBA) map of Alaska that was compiled by Meyer in 2008 (Figure 7). Their Bouguer anomaly map is based on the standard reduction density of $2670 \mathrm{~kg} / \mathrm{m}^{3}$, a free-air correction of $3.086 \times 10^{-3} \mathrm{~mm} / \mathrm{s}^{2}$ and a terrane correction to a radius of $166.7 \mathrm{~km}$ derived from the method of Plouff (1977) [36]. To better understand and model the gravity anomaly patterns caused by shallow sources with contrasting densities in the two basins, we separated the regional (long wavelength) and residual (short 
wavelength) gravity field components through the least squares method using polynomial surfaces for nine gravity transects [37]. The low-density root of the topographically high Central Alaska Range is removed with well-constrained assumptions: (1) depth to isostatic root (Moho) at sea level $=35-45 \mathrm{~km} \mathrm{[34]} \mathrm{and} \mathrm{(2)} \mathrm{average} \mathrm{density} \mathrm{of} \mathrm{basement}$ masses $=2600-2700 \mathrm{~kg} / \mathrm{m}^{3}$ [34,37]. A close correlation was achieved between the residual gravity anomalies and the observed geological boundaries. The calculated residual gravity anomalies for nine gravity transects were contoured using Surfer 12 [38] (Figure 8).

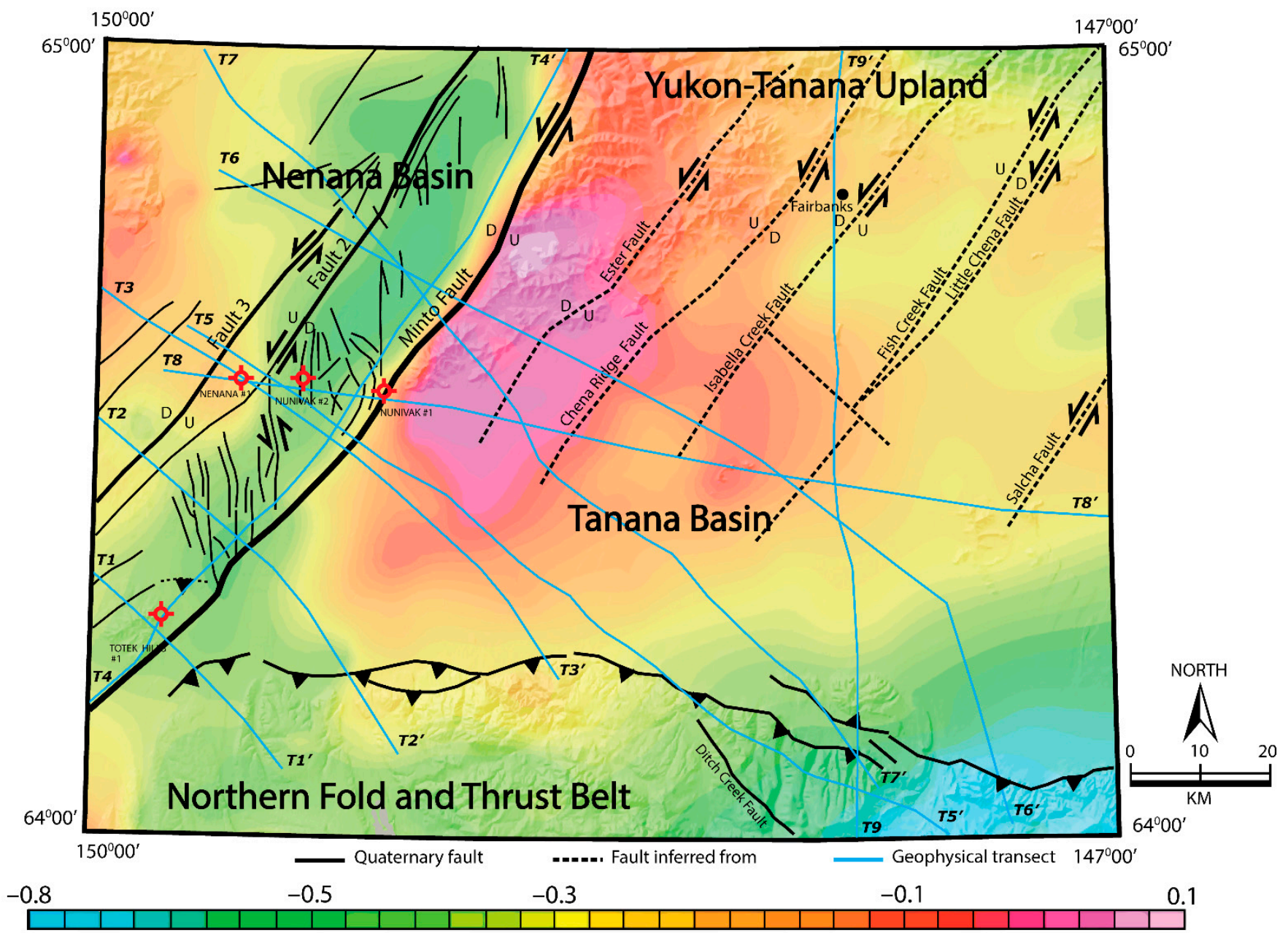

Complete Bouguer Gravity Anomaly $\left(\mathrm{mm} / \mathrm{s}^{2}\right)$

Figure 7. The complete Bouguer gravity anomaly map of the Fairbanks quadrangle, central Alaska. Maps are modified from Meyer [39]. Solid blue lines indicate the geophysical transects presented in our study.

\subsubsection{Magnetic Anomaly Data}

The high-resolution total magnetic intensity anomaly map of Central Alaska was used to constrain shallow causative magnetic features within the upper crust of our study area (Figure 9). This map was constructed from merged aeromagnetic surveys [40] that were conducted during the years 1971 to 1973. Data were acquired along 1-mile-spaced flight lines at a height of about $305 \mathrm{~m}$. The residual magnetic anomalies along 9 transects were used as the input to our potential field models. 


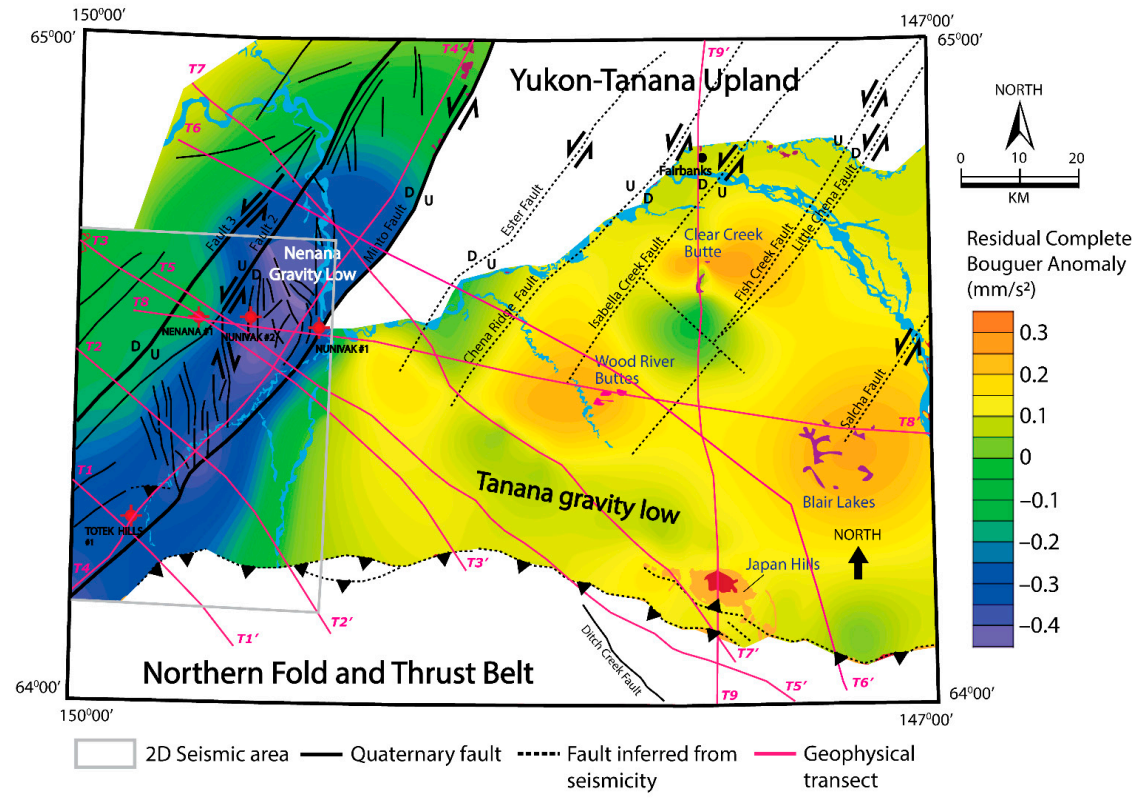

Figure 8. The final residual gravity anomaly map of the study area. The residual gravity field was calculated by isolating the long-wavelength regional gravity field using polynomial approximation methods.

(A)

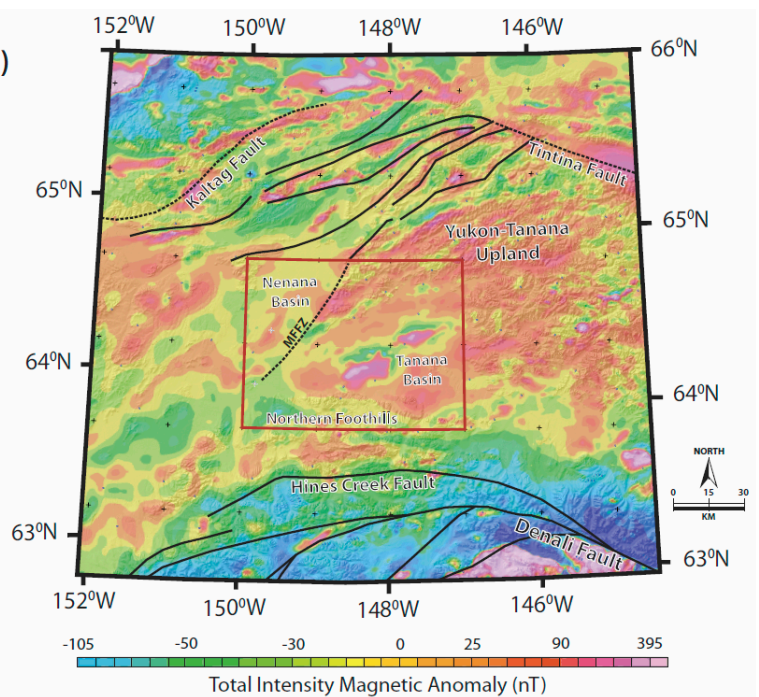

(B)

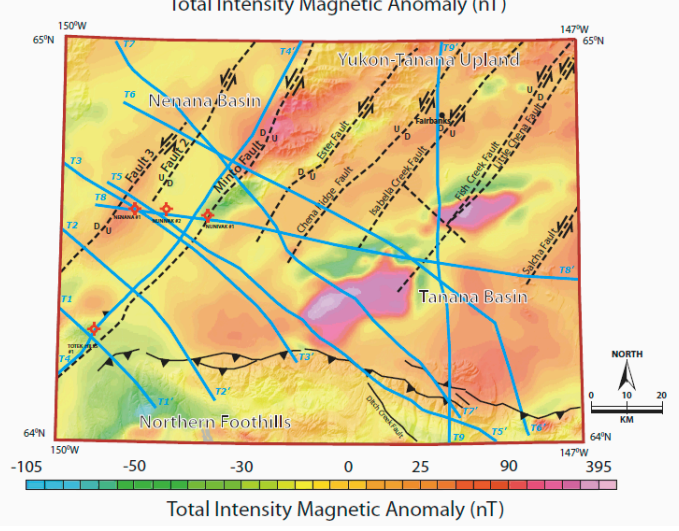

Figure 9. (A) The regional magnetic anomaly map. (B) Magnetic anomaly map of the Fairbanks quadrangle, Central Alaska. Maps are modified from Meyer [39]. Solid blue lines indicate the geophysical transects presented in our study. 


\subsection{Two-Dimensional (2D) Forward Modelling}

Nine profiles were selected roughly perpendicular to the strike of major geologic structures and the gradients of the prominent anomalies (T1 to T9; Figures 3, 7 and 9). We used GM-SYS, a 2D gravity and magnetic interactive forward modeling software, to generate subsurface models that honor the observed residual gravity and residual magnetic anomaly data as well as the known distribution and physical properties of major geologic units. Each 2D profile generated in this study constrains a shallow-crustal model for the subsurface position, shape, thicknesses, physical properties and depths of these units. Modeled blocks are assumed to have homogeneous densities and magnetic susceptibilities.

Observed gravity and magnetic anomalies at the surface can result from several earth models, many of which may not be geologically realistic. To remove this inherent ambiguity in determining realistic potential field sources, an initial potential field model was developed in GM-SYS, and it was further constrained by existing geophysical and geological data, assuming each structural/lithologic block to extend to the infinity in a direction perpendicular to the profile. In GM-SYS software version 7.1, the joint modeling for calculated gravity and magnetic responses was performed using the methods of Talwani et al. (1959) [41] and Talwani and Heirzler (1964) [42]. Forward gravity and magnetic models were then generated, based on algorithms described by Won and Bevis (1987) [43]. Each potential field model was then used to estimate a hypothetical potential field signature that was compared to the observed residual gravity and magnetic data. The geometries and rock physical properties of the assumed geophysical sources were then iteratively modified to obtain a best fit between the observed and calculated values of both gravity and magnetic anomaly data.

For the final potential field models of the Nenana basin and Tanana basin, the intrabasement sources were attributed to Proterozoic to Early Paleozoic Yukon-Tanana Terrane schist (regional schist sequences) and Late Paleozoic Totatlanika schist underlying the basin sequences (Table 1). A suite of Late Cretaceous to Early Tertiary mafic and plutonic intrusions were modeled as separate higher-density bodies similar to those seen at the surface and inferred in published geophysical cross-sections for Interior Alaska [28,30,44]. Sedimentary sequences that are exposed in Interior Alaska and are incorporated into the model include Late Paleocene and older sediments, Miocene Usibelli Group strata, Pliocene Nenana Gravel, and Quaternary and younger surficial deposits $[26,27,45]$. Table 1 shows the representative densities and magnetic susceptibilities assigned to each modeled unit.

The aeromagnetic data were modeled for only five selected profiles (T1, T2, T3, T5 and T7), due to the availability of magnetic susceptibility data and geologic information about the nature of bedrock in the study area.

\section{Results and Discussion}

Our final integrated potential field models show the best of the possible solutions that are well constrained by seismic reflection data and the available sources of other geophysical and geologic data. The errors in the least square fitting between the observed and computed profiles were $0.7 \%$ for gravity and $31 \%$ for the magnetic data. The misfit for gravity and magnetic profiles could be the result of local changes in rock densities and uncertainty about the direction of magnetization [46]. It, however, can be improved by splitting sources into a large number of homogeneous bodies with variable densities and magnetization properties. However, the degree of heterogeneity within the source body is hard to constrain and relies mostly on the consistency with the available geologic and geophysical data for the Central Alaska region and geologic concepts.

Below, we discuss the two basins separately due to variations in their basement structure as well as available geological and geophysical information for each basin. See the Appendix A for more details. 


\subsection{Tanana Basin}

The potential field data for Tanana basin is consistent with a broad and shallow basin (Figure 10). The depth-to-basement inferred from our potential field analysis suggests that the sedimentary cover of the Tanana basin thickens from $\sim 900 \mathrm{~m}$ along the northern margin of the basin against the Yukon-Tanana Upland to $\sim 1.5 \mathrm{~km}$ in the south, immediately north of the northern foothills fold-and-thrust belt (Figure 11).
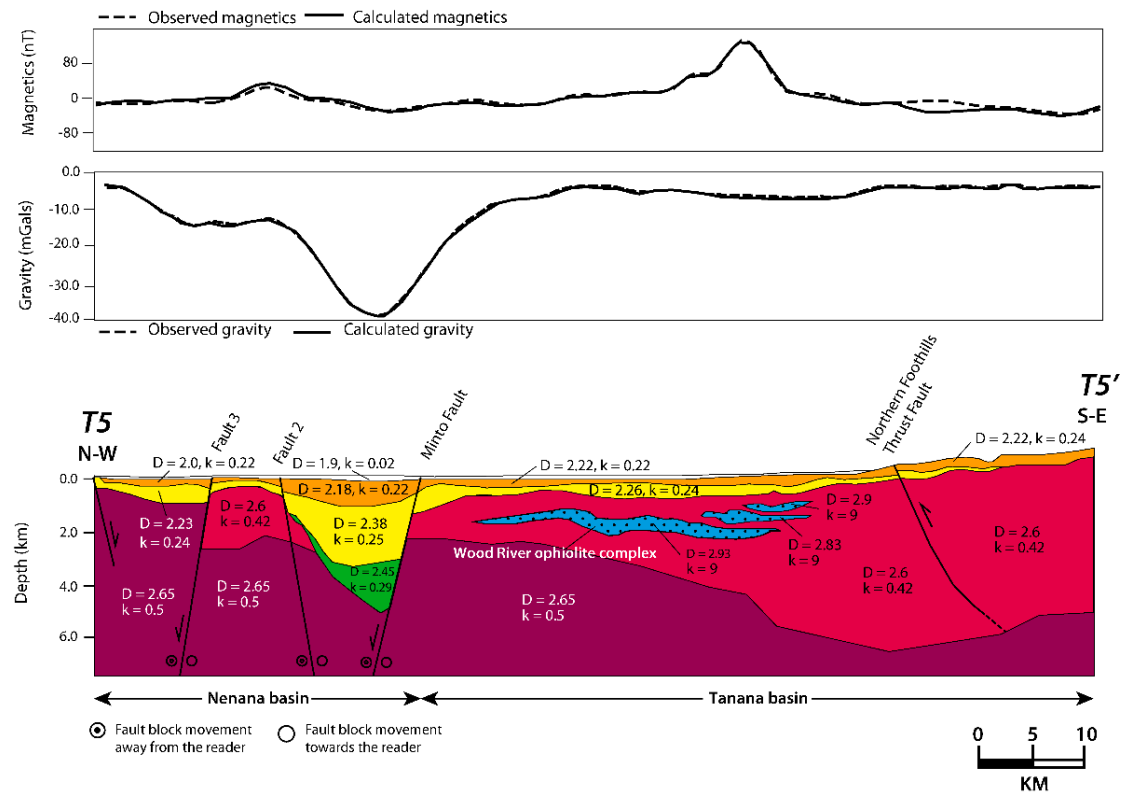

(A)

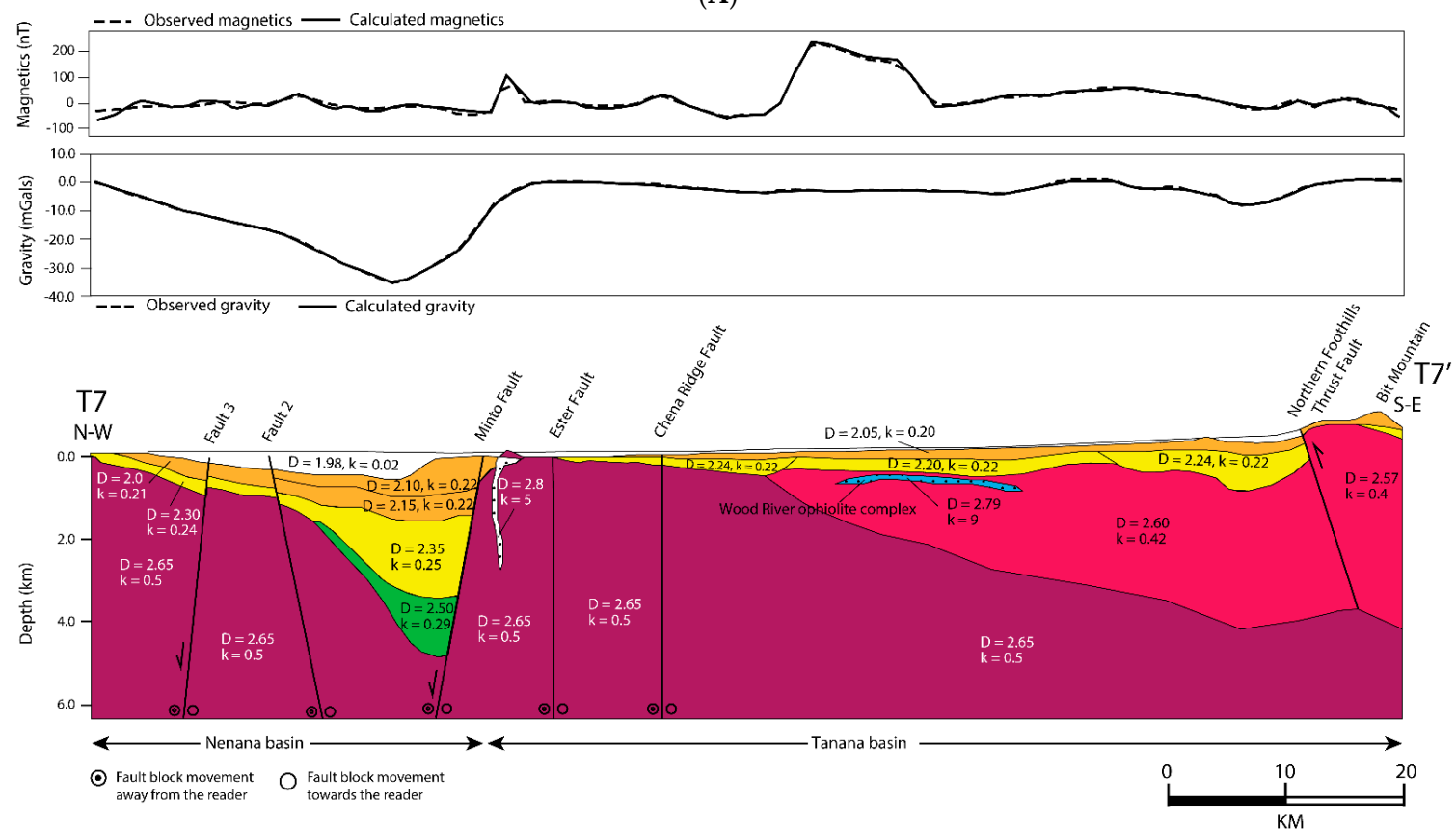

(B)

Figure 10. A total of $2 \frac{1}{2}$ gravity and magnetic models across the Tanana basin. (A) Model T5 is oriented NW-SE across the southern part of the Nenana basin. (B) Model T7 strikes NW-SE across the northern part of the Nenana basin. The profile locations are shown in Figure 3. The upper panels show observed (dotted black line) and calculated (solid black line) gravity and magnetic anomaly curves. The lower panel shows the potential field model with individual source bodies colored by lithology and labeled with density $\left(\times 10^{3} \mathrm{~kg} / \mathrm{m}^{3}\right)$ and magnetic susceptibility $\left(\times 10^{3} \mathrm{SI}\right)$. Blue dotted line shows the limit of seismic reflection data in our study area. Table 1 summarizes measured average magnetic susceptibility and rock density values for modeled lithologic units in our study area. 


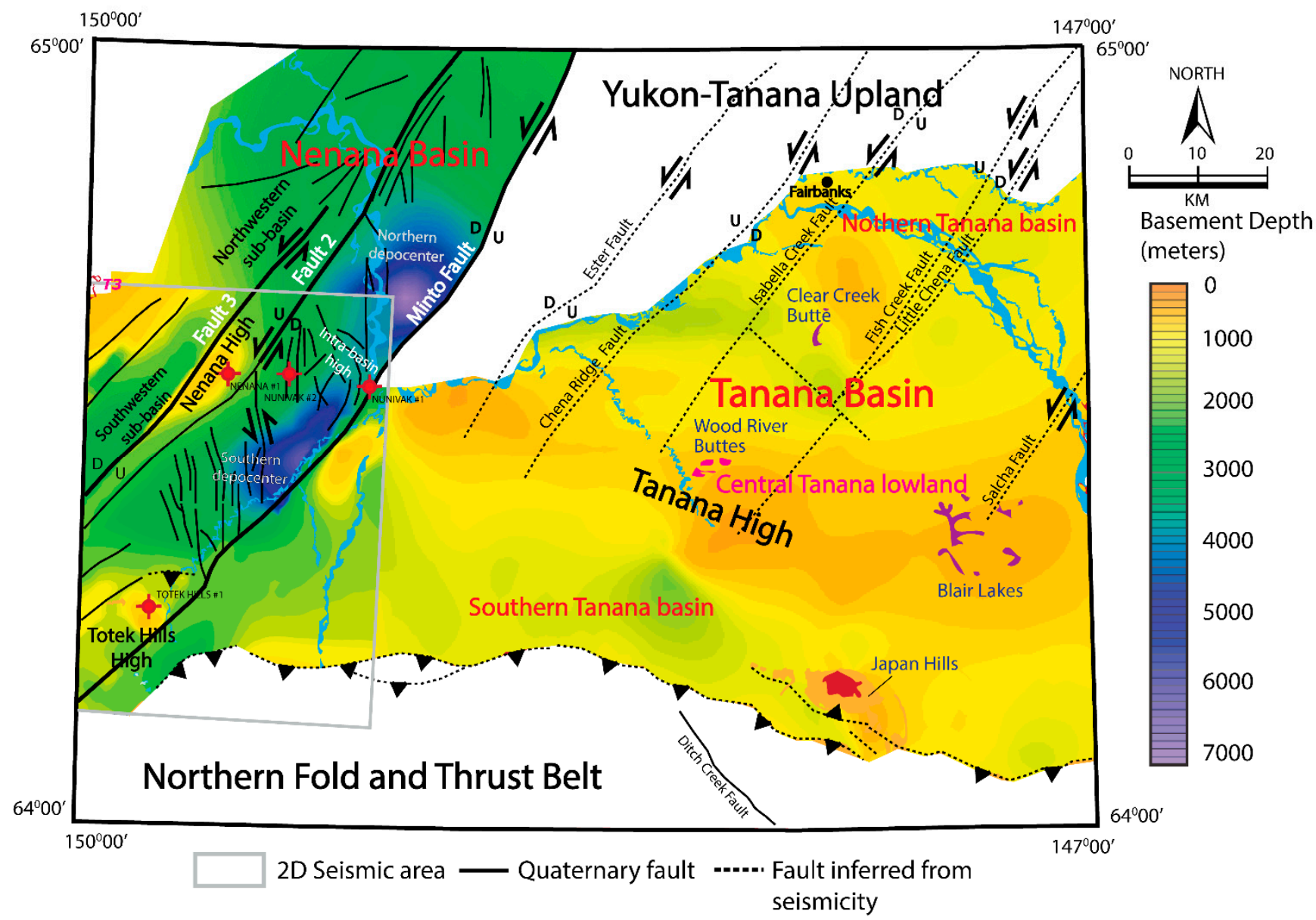

Figure 11. Basement depth map from integrated seismic and potential field models of both the Nenana and Tanana basins. While the composition of the crust underlying the two basins is similar, the distribution and thicknesses of the overlying sedimentary sequences vary greatly. Overall, the sedimentary fill in the Nenana basin is significantly thicker (up to $8 \mathrm{~km}$ ) and probably older than that in the Tanana basin (up to $2 \mathrm{~km}$ thick).

Our integrated potential field models have identified three distinct geologic provinces within the Tanana basin: the Southern Tanana basin, the Tanana High and the Northern Tanana basin (Figure 11).

\subsubsection{The Southern Tanana Basin}

The Southern Tanana basin province extends northward from the northern limit of foothills on the north side of Alaska Range into the Central Tanana Lowland. Based on observed gravity and magnetic anomaly signatures for the area, we modeled two principle rock units: (1) the Tertiary sedimentary sequences of the Tanana basin with low densities and low magnetic susceptibilities that are interpreted to be the source of gravity and magnetic anomaly lows and (2) dense to very dense Precambrian Yukon-Tanana schists with metamorphic grades varying locally between greenschist and amphibolite facies, and younger greenschist facies of Paleozoic rocks such as the Totatlanika Schist are interpreted to be the source of prominent high magnetic and gravity anomalies (Figure 10, Table 1). The magnetic anomaly pattern over the northern foothills of the Alaska Range shows a broad east-west-trending, low-amplitude negative anomaly (up to $25 \mathrm{nT}$ ) (Figure 9). This pattern is roughly parallel to the fold axes in the northern foothills fold-and-thrust belt. Our preferred interpretation for this magnetic low is the contrasting properties posed by a thick cover of weak magnetic Neogene sediments (up to $\sim 2 \mathrm{~km}$ thick) that are well exposed on the northern flank of the central Alaska Range [7] (Figure 2). We tested this hypothesis by assigning an average density of $2240 \mathrm{~kg} / \mathrm{m}^{3}$ and magnetic susceptibility averaging 0.00015 SI to the Neogene sedimentary sequences and basement rocks to values 
of $2600 \mathrm{~kg} / \mathrm{m}^{3}$ and $0.0005 \mathrm{SI}$, respectively, up to a depth of $7.5 \mathrm{~km}$ (Figure 10). The resulting potential field models provided the best fit to the observed anomaly data as expected.

Further to the east, a prominent magnetic high $(\sim 60 \mathrm{nT})$ that extends across the Japan Hills has been interpreted in our potential field models as a positive anomaly produced by the exposed Totatlanika schist [47] (Figures 2,9 and 10). These authors suggested that the Pliocene Nenana gravel in this area were possibly eroded away or pinched out along the crest of the Japan Hills and were too thin to produce measurable positive magnetic anomalies at this site.

Ridgway et al. (2007) [26] suggested that the southern part of the Tanana basin is actively deforming due to flexural subsidence related to northward propagation of the Neogene northern foothills fold-and-thrust belt of the Central Alaska Range. Our potential field models for this area agree their interpretation and further show that the depth to the basement of the Tanana foredeep increases to the south (Figure 11). Neogene sediments reach a maximum thickness of $\sim 1.5 \mathrm{~km}$ in the Tanana foredeep region.

\subsubsection{The Tanana High}

The Tanana High province is modeled to accommodate a prominent northeast-trending belt of significantly high-amplitude magnetic anomalies ( $500 \mathrm{nT})$ that cross the lowland south of the Wood River Buttes and Clear Creek Butte (Figures 2 and 9). The source of these intense magnetic anomalies corresponds to mafic and ultramafic rocks exposed in the vicinity of the Wood River Buttes [48] (Figures 2 and 10). These rocks are composed mainly of diorite and serpentinized peridotite and are interpreted as an ophiolite included in Seventymile terrane in Central Alaska $[49,50]$. The anomaly can be modeled as a shallow (maximum $3 \mathrm{~km}$ deep) serpentinized body with a thickness of $1600 \mathrm{~m}$ and extending as far as $15 \mathrm{~km}$ southward of the Wood River Buttes (Figure 10). The limited size of the magnetic anomalies indicates that the anomalous rocks are discontinuous.

\subsubsection{The Northern Tanana Basin}

An anomalous negative magnetic anomaly $(\sim 60 \mathrm{nT})$ near the town of Nenana was modeled as a dike-like intrusive body with an average density of $2770 \mathrm{~kg} / \mathrm{m}^{3}$ and magnetic susceptibility of 0.005 SI (Figures 2 and 10). We interpret this body to represent mafic plutonic rocks that intruded the Yukon-Tanana Upland in Late Cretaceous or in Early Tertiary time [51]. The early Tertiary igneous rocks are typically reverse polarized, causing a negative magnetic anomaly [52].

The northern part of the Tanana basin is generally characterized by a belt of eastto-west-trending, positive low-amplitude magnetic anomalies (up to $25 \mathrm{nT}$ ) (Figure 9). These anomalies have gravity lows associated with them (up to $0.12 \mathrm{~mm} / \mathrm{s}^{2}$ ), which suggests localized relatively thicker sedimentary cover in the northern part of the Tanana basin (Figure 8). Geomorphic studies by Lesh and Ridgway (2007) [25] suggest that the drainage pattern of the Tanana basin exhibits northward dipping of the basement surface of the Tanana basin along its northern margin. We interpret the northern margin of the Tanana basin as a structural low bounded to the north by the topography of the Yukon-Tanana Upland.

\subsection{Nenana Basin}

The seismic reflection data, combined with the 2D potential field models for the Nenana basin show Cenozoic sedimentary fill as thick as $\sim 6 \mathrm{~km}\left(-0.28 \mathrm{~mm} / \mathrm{s}^{2}\right)$ along the southern part and $\sim 8 \mathrm{~km}\left(-0.42 \mathrm{~mm} / \mathrm{s}^{2}\right)$ along the northern part of the basin (Figure 12). Based on density variations, we modeled the sedimentary rock sequences of the Nenana basin in four rock packages: (1) Late Paleocene and older sediments (up to $\sim 2100 \mathrm{~m}$ thick), (2) Miocene Usibelli Group sediments (up to $\sim 4 \mathrm{~km}$ thick), (3) Pliocene Nenana Gravel (up to $\sim 1300 \mathrm{~m}$ thick), and (4) Quaternary surficial deposits (up to $\sim 500 \mathrm{~m}$ thick) (Figure 12; Table 1). 


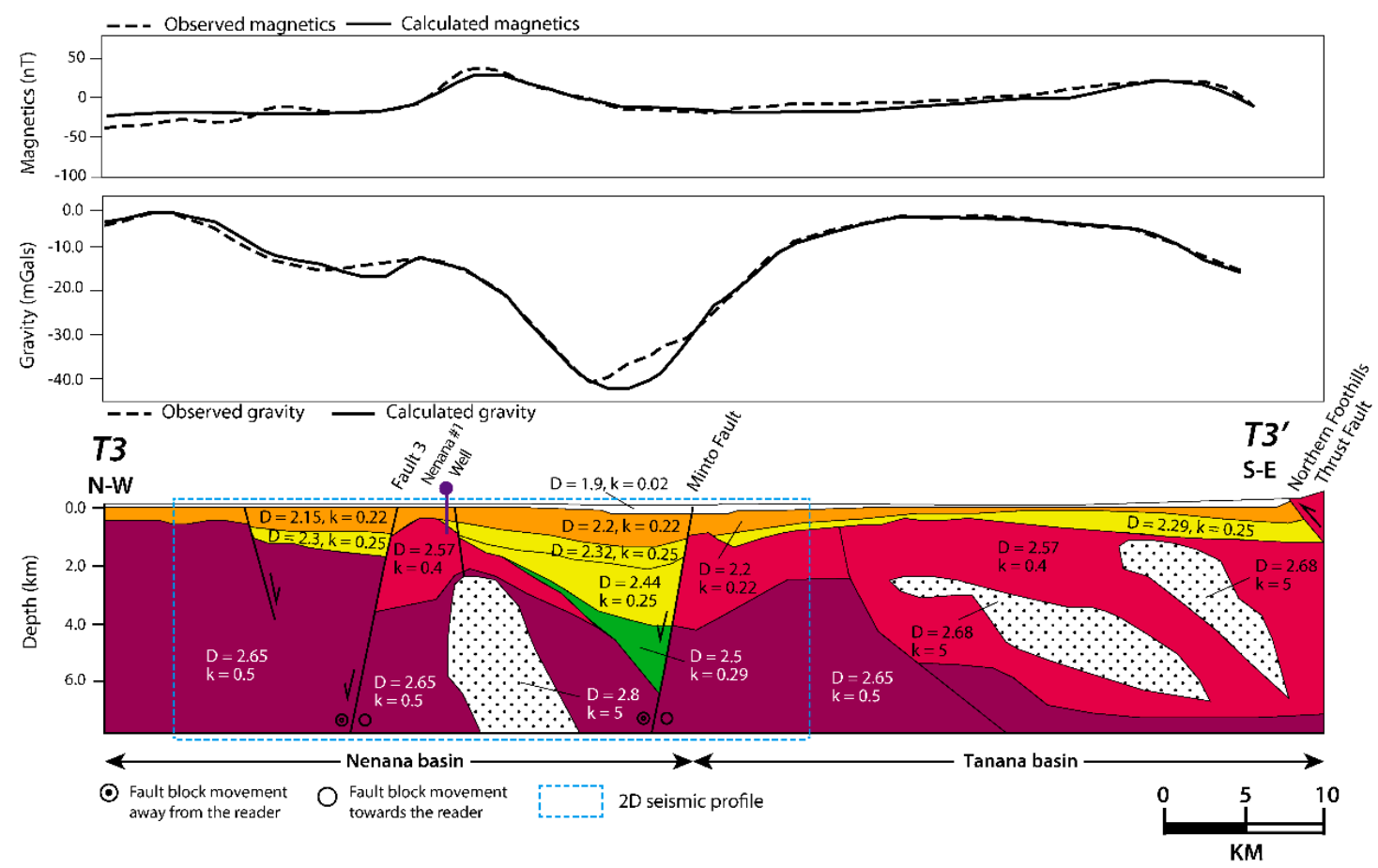

(A)
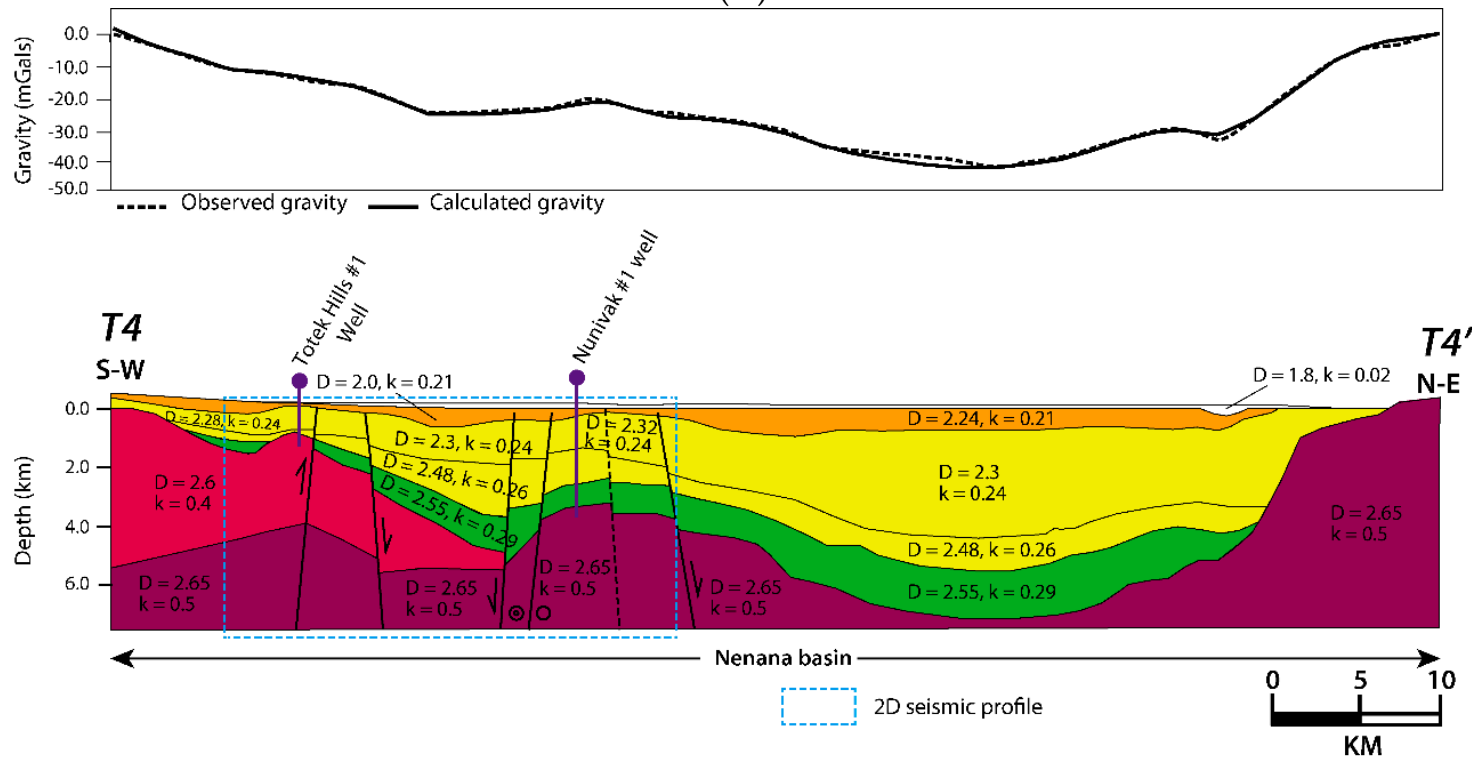

(B)

Figure 12. A total of $2 \frac{1}{2}$ gravity and magnetic models across the Nenana basin. (A) Model T2 is oriented NW-SE across the southern part of the Nenana basin. (B) Model T4 is oriented NE-SW, parallel to the strike of the Nenana basin. The profile locations are shown in Figure 3. The upper panels show observed (dotted black line) and calculated (solid black line), gravity and magnetic anomaly curves. The lower panel shows the potential field model with individual source bodies colored by lithology and labeled with density $\left(\times 10^{3} \mathrm{~kg} / \mathrm{m}^{3}\right)$ and magnetic susceptibility $\left(\times 10^{3} \mathrm{SI}\right)$. Blue dotted line shows the limit of seismic reflection data in our study area. Table 1 summarizes measured average magnetic susceptibility and rock density values for modeled lithologic units in our study area.

Our potential field models indicate that the sedimentary fill thickens along the eastern and northeastern flank of the basin to as much as $7 \mathrm{~km}$ against the Minto Fault-a prominent north-east striking left-lateral fault bounding the northern depocenter of the Nenana basin (Figures 11 and 12). The Minto Fault is modeled as a steep, west-dipping $\left(\sim 76^{\circ}\right.$ dip with strike of $\left.10^{\circ}\right)$ oblique-extensional fault that juxtaposes the Cenozoic sediments of the basin against denser Precambrian to Paleozoic quartz mica schists of the 
Yukon-Tanana terrane [19]. A strong contrast in gravity and magnetic anomalies along the northeastern flank of the Nenana basin is attributed to the main trace of Minto Fault with east-side up (Figures 8 and 9). Our interpretation is consistent with mapped seismic lineaments of the Minto Fault in previous geophysical investigations $[19,22]$ and geomorphic analyses [8,9]. The Nenana basin gradually deepens from south to north over a distance of $60 \mathrm{~km}$, after which it reaches the maximum depth $7 \mathrm{~km}$ to the north of the Nunivak \#1 well site (Figure 11).

Northwest-striking oblique faults were modeled to the west of the Minto Fault in the Nenana basin (Figures 5 and 11). These faults appear to accommodate the sinistral motion component locally between the major basin-bounding faults, the Minto Fault and Fault 2 [19]. Tape et al. (2015) [10] also identified northwest-striking fault (Event K, fault strike $-150^{\circ}$ ) to the east of the Minto Fault that suggests ongoing secondary extension across the northwest-striking oblique faults in the basin.

The basin shallows gradually to the southwest (Figure 11). The Totek Hills physiographic region is a prominent structural high in this area and is a notable feature on seismic data with the depth to basement $(\sim 1 \mathrm{~km})$ well-constrained at the Totek Hills \#1 well site (Figures 6 and 12). This structural high is defined by a steeply dipping reverse fault on seismic reflection data and the exposed Miocene rocks of the Usibelli Group in the region (Figures 2 and 6).

The western margin of the Nenana basin is characterized by a major, northeasttrending high amplitude positive magnetic anomaly $\left(\sim 0.30 \mathrm{~mm} / \mathrm{s}^{2}\right)$. We modeled this magnetic high, hereafter called the Nenana High, as the result of a buried basement high that plunges smoothly to the southwest (Figure 12). A relatively high gravity anomaly $\left(0.10 \mathrm{~mm} / \mathrm{s}^{2}\right)$ coincides directly with this magnetic anomaly and supports the interpretation of a basement high at a shallow depth along the western margin of the Nenana basin. To the west of the Nenana High, a low-amplitude $\left(-0.18 \mathrm{~mm} / \mathrm{s}^{2}\right)$ gravity anomaly was modelled as the Southwestern Nenana Sub-basin with sediment thickness about $1800 \mathrm{~m}$ (Figures 11 and 12).

\subsection{Intrusive Rock Bodies}

Intrusive bodies with high densities and magnetic susceptibilities were modeled to resolve short wavelength magnetic highs observed in both Nenana and Tanana basins (Figures 10 and 12). Late Cretaceous and Tertiary intrusions ranging in size from small plutons to batholiths are exposed throughout the Yukon-Tanana Upland and are thought to be present in the subsurface throughout the Yukon-Tanana terrane in the southeastern part of the Fairbanks quadrangle [53]. The compositions of these intrusive rocks are between mafic to felsic $[13,54]$. The magnetic susceptibility of Cretaceous granites such as the Walker Fork pluton exposed in the Yukon-Tanana Upland ranges from 0.003 to 0.030 SI [55]; a magnetic susceptibility of $0.005-0.009$ SI and bulk density of $2750-2900 \mathrm{~kg} / \mathrm{m}^{3}$ were used to model potential intrusive rocks in our study area (Table 1).

\section{Styles of Tectonic Deformation in Central Interior Alaska}

\subsection{Tanana Basin-Asymmetric Foreland Basin with Bookshelf Faulting}

Based on our modeling efforts, we divide Tanana Basin into two distinct domains with different basement characteristics. "The bookshelf faulting zone" comprises the Northern Tanana basin and is underlain by northwest-striking active faults. "The foreland basin zone" is composed of the Southern Tanana Basin and the leading edge of the northern foothills fold-and-thrust belt of the Alaska Range. The boundary between the two zones is the Tanana High. We propose a model of tectonic deformation for the Tanana basin that explains the character of these zones and their interaction.

Our model expands on the model proposed by Ridgeway et al. $(2002 ; 2007)[26,56]$ but incorporates the northeast striking faults observed in the bookshelf faulting zone. In this model, the southern part of the basin (Figure 13) is the leading edge of the thick-skinned fold and thrust belt of the Alaska Range that is encroaching on and deforming the proximal 
foreland basin sediments of the Tanana Basin. The thick continental crust in this region of the Central Alaska Range bends to a lesser extent and, therefore, restricts the size and depth of the foreland basin. In this model, the Tanana High may be either the forebulge of the foreland basin [57] or, alternatively, may be a pre-existing basement high.

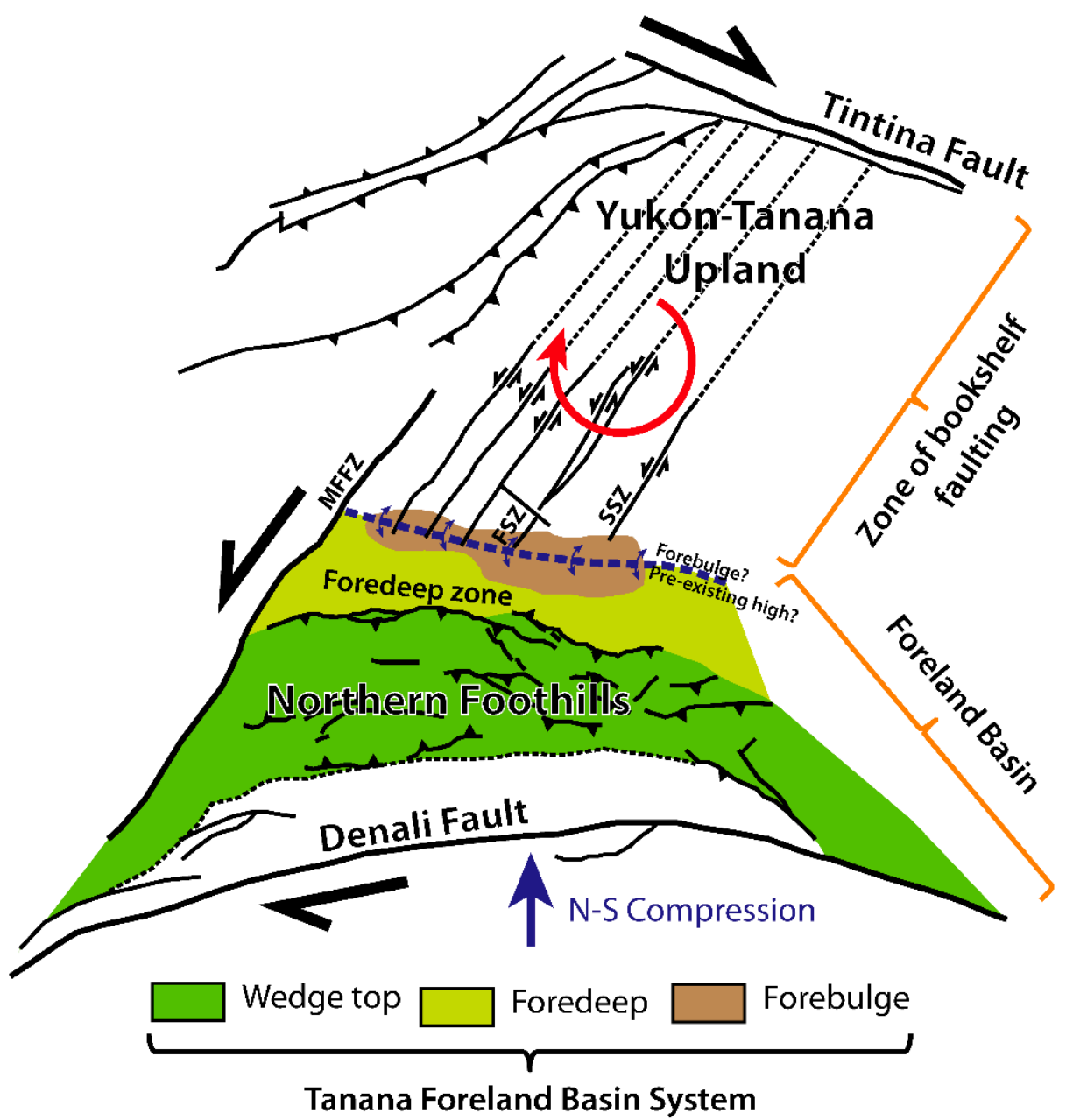

Figure 13. Simplified foreland-flexural deformation model presented for the Tanana basin in which the thrust belt of the Alaska Range drives north-south directed shortening in the basin. North of the thrust belt, progressive flexural subsidence due to crustal loading causes the development of the foredeep along the northern margin of the foothills of the northern Alaska Range. In this model, the Tanana High is the forebulge of the Alaska Range foreland basin or, alternatively, is a basement high underlain by the leading edge of the Alaska Range fold-and-thrust belt. Compression north of the Tanana High drives clockwise rotation of crustal blocks facilitated by left-lateral motion on northeast-striking faults, marked by a zone of bookshelf-style faulting and rotation.

In the Northern Tanana Basin, north-south directed shortening in the foreland basin zone causes contemporaneous left-lateral strike-slip displacements on the northeast-striking fault systems in the north (Figure 13). The regional convergence results in clockwise rotation of fault blocks in the bookshelf faulting zone around a pole of rotation located at the Yukon-Tanana Upland in the north. As crustal shortening in the foreland basin zone is taken up by the bookshelf-style rotation of the crustal blocks, the continental crust in this region stays relatively flat and unfolded.

\subsection{Nenana Basin-Transtensional Pull-Apart Basin}

This model builds upon a model proposed by Dixit and others (2017) [19]. In this model, the Nenana basin initiated during Paleocene time as a single depression within an 
extensional half-graben system. This is supported by the asymmetry of the basin and early basin fill [22]. This half-graben structure was subsequently modified by later left-lateral strike-slip faulting in a transtensional stress regime since the late Miocene [19] (Figure 14).
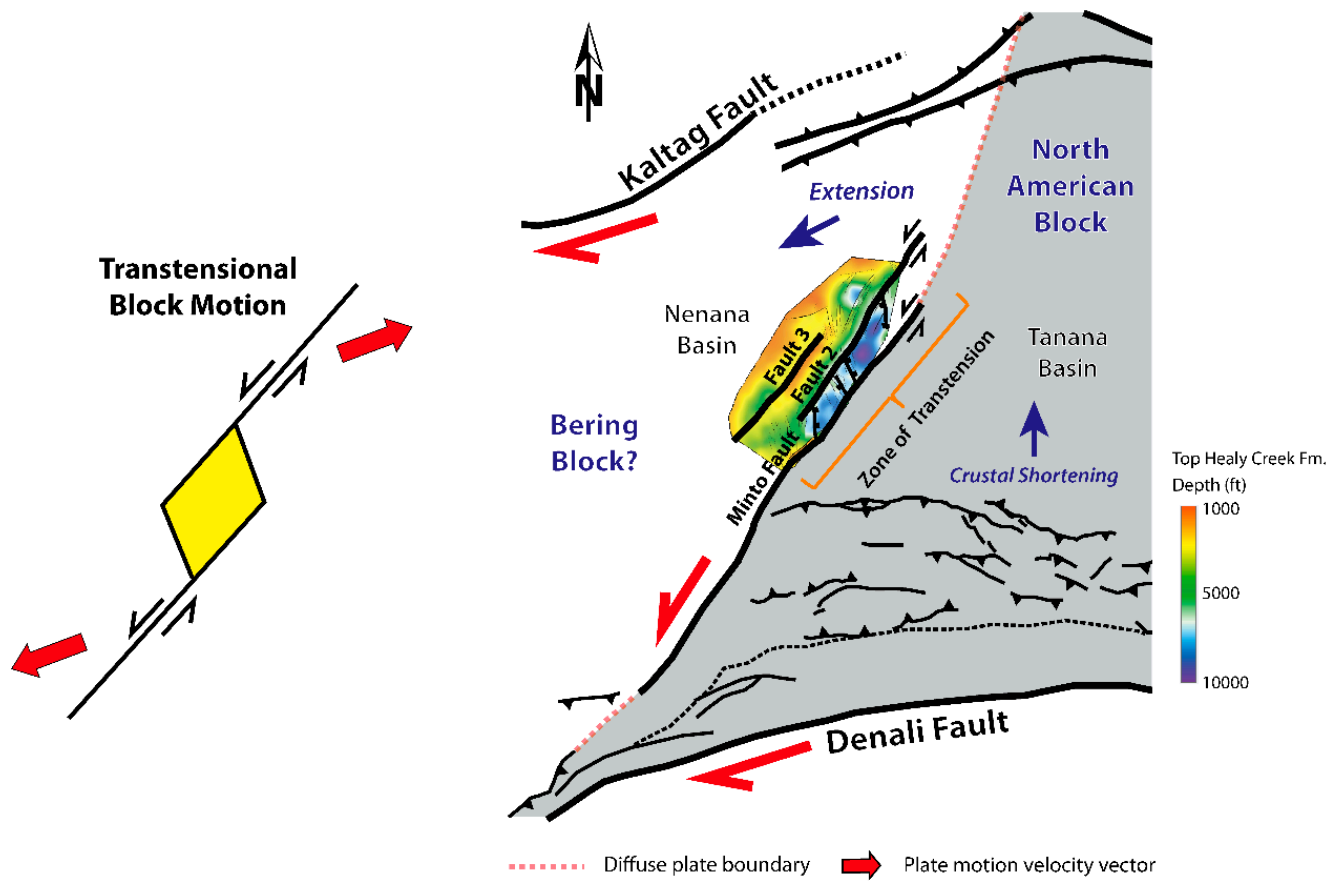

Nenana Transtensional pull-apart basin

Figure 14. Simplified tectonic deformation model of the transtensional Nenana pull-apart basin. In this model, two left-lateral, oblique-slip master faults (Minto Fault and Fault 2) overlap, forming a releasing bend. A cross-basin transverse fault zone, marked by a distinct intra-basin high, further divides the basin into two discrete depocenters. The geometries of these basin depocenters are further controlled by the oblique-extensional deformation along the major basin-bounding faults (Fault 2 and Minto Fault). The formation of sub-basins along the western margin of the Nenana basin exhibits SW-ward extrusion of Bering block relative to the North American craton.

As transtension initiated, the basin started opening and deforming along a stepover zone between the left-lateral strike-slip faults (in this case, Minto Fault and Fault 2). As the transtensional deformation continued, a cross-basin strike-slip fault formed connecting left-lateral master faults. The intra-basin high developed across this cross-basin strike-slip fault above the center of the basin, further dividing the basin in dual opposing depocenters (northern and southern Nenana depocenters). At present, each of the depocenters is bound on one side by the basin-bounding major oblique extensional fault. In addition, sub-basins observed along the western margin could represent a series of incipient half-grabens that developed in response to transtensional motion [58] (Figure 14).

In summary, the results of our study demonstrate two different styles of tectonic deformation for Central Alaska (Figure 15). The Tanana basin is a relatively shallow (up to $2 \mathrm{~km}$ ) asymmetrical foreland basin with its southern, deeper side controlled by the northern foothills of the Central Alaska Range. Northeast-trending strike-slip faults within the Tanana basin exhibit a zone of clockwise crustal block rotation. The Nenana basin has a fundamentally different geometry: it is a deep (up to $8 \mathrm{~km}$ ), narrow transtensional pull-apart basin that is deforming along the major basin-bounding faults. 


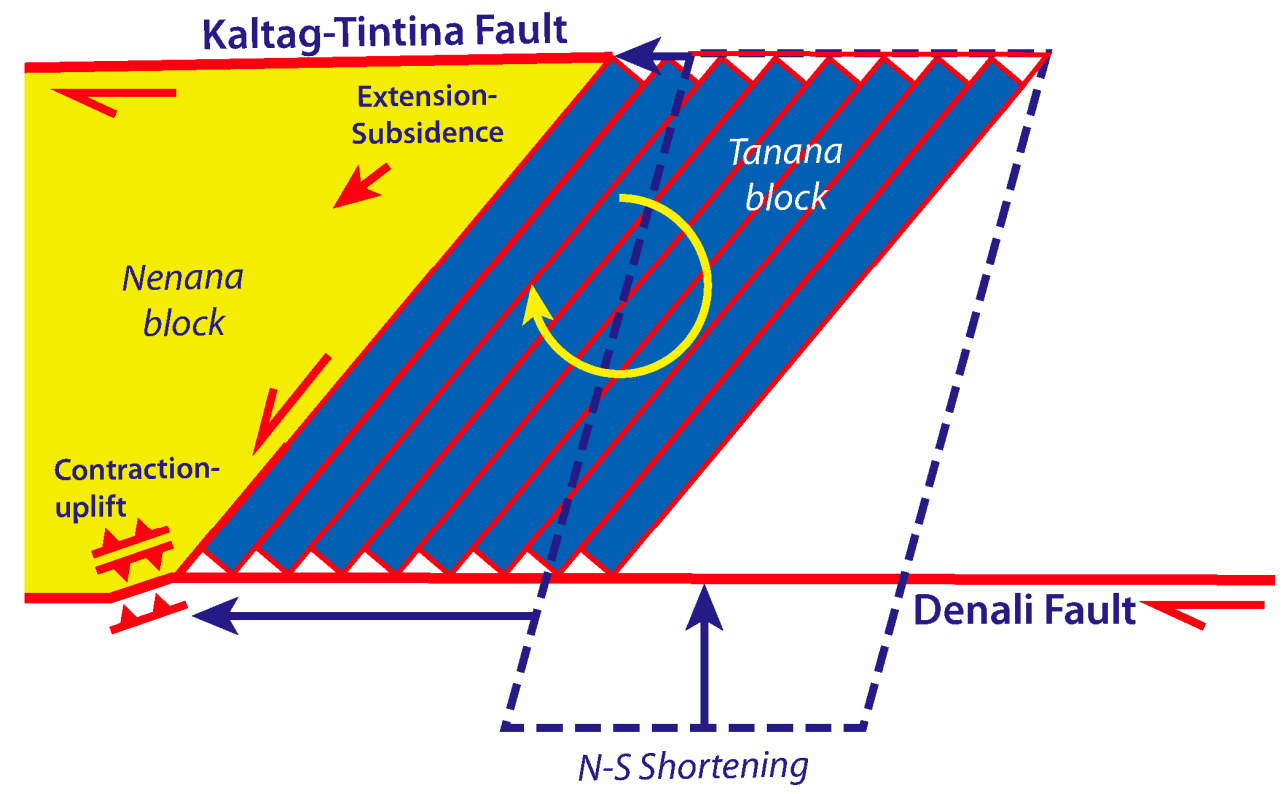

Figure 15. Simplified regional tectonic deformation model proposed for Central Interior Alaska.

\section{Conclusions}

Analysis of regional gravity and magnetic anomaly data, in combination with geological, seismic reflection and seismicity data, constrain the basement structure and the styles of tectonic deformation in central Alaska. Nine well-constrained potential field models show that although the Nenana basin and Tanana basin appear contiguous and are underlain by crustal rocks of similar compositions, the two basins differ significantly in crustal geometry and age. The Nenana basin is a narrower and deeper (12-15 km wide and up to $8 \mathrm{~km}$ deep) depression that contains sediments estimated to be as old as Paleocene age, whereas the Tanana basin is a significantly wider and shallower basin (up to $1.5 \mathrm{~km}$ deep) filled with sediments that probably date Miocene and younger ages.

Three distinct structural provinces have been identified in the Tanana basin (1) based on the strike-slip province characterized by bookshelf-style rotation of northeast-oriented fault blocks, (2) a central province associated with strong gravity and magnetic character that is attributed to the regional basement high, the Tanana High and (3) a southern foldand-thrust province displaying a well-defined anomaly low associated with the deepening of basement due to flexural deformation.

The modern-day structural configuration of the Nenana basin is interpreted as an oblique-extensional pull-apart zone that is significantly different from the compressionaltype setting inferred for the Tanana basin. Both basins, therefore, highlight two separate zones of crustal deformation in Central Interior Alaska.

Author Contributions: N.C.D. and C.H. conceptualized and designed the research problem. N.C.D. identified the methods and performed the analyses of potential fields, seismic reflection and well log data. N.C.D. wrote the paper. C.H. reviewed the original draft of the paper. All authors have read and agreed to the published version of the manuscript.

Funding: The United States Air Force Office of Scientific Research supported this research under award number FA9550-11-1-0006.

Institutional Review Board Statement: Not applicable.

Informed Consent Statement: Not applicable.

Data Availability Statement: The data presented in this study are available on request from the corresponding author. 
Acknowledgments: Special thanks to the Alaska Division of Oil and Gas, University of Alaska Fairbanks' Geophysical Institute and the Department of Geosciences for additional financial support. We would like to thank Carla Tomsich for her invaluable help and guidance in all aspects of potential field modeling, field sampling and sample preparations. We are also grateful to Douglas Moore and ConocoPhillips for kindly providing seismic data; Kenneth Papp from GMC for sharing well information; Michelle Hayhurst from Platte River Associates for donating BasinMod software, and Bernard Coakley, Wes Wallace and Paul McCarthy for helpful comments on the manuscript.

Conflicts of Interest: The authors declare no conflict of interest.

\section{Appendix A}

$2 \frac{1}{2}$ gravity and magnetic models across the Nenana and Tanana basins. The upper panels show observed (dotted black line) and calculated (solid black line) gravity and magnetic anomaly curves. The lower panel shows the potential field model with individual source bodies colored by lithology and labeled with density $\left(\times 10^{3} \mathrm{~kg} / \mathrm{m}^{3}\right)$ and magnetic susceptibility $\left(\times 10^{3} \mathrm{SI}\right)$. Blue dotted line shows the limit of seismic reflection data in our study area. Table 1 summarizes measured average magnetic susceptibility and rock density values for modeled lithologic units in our study area.
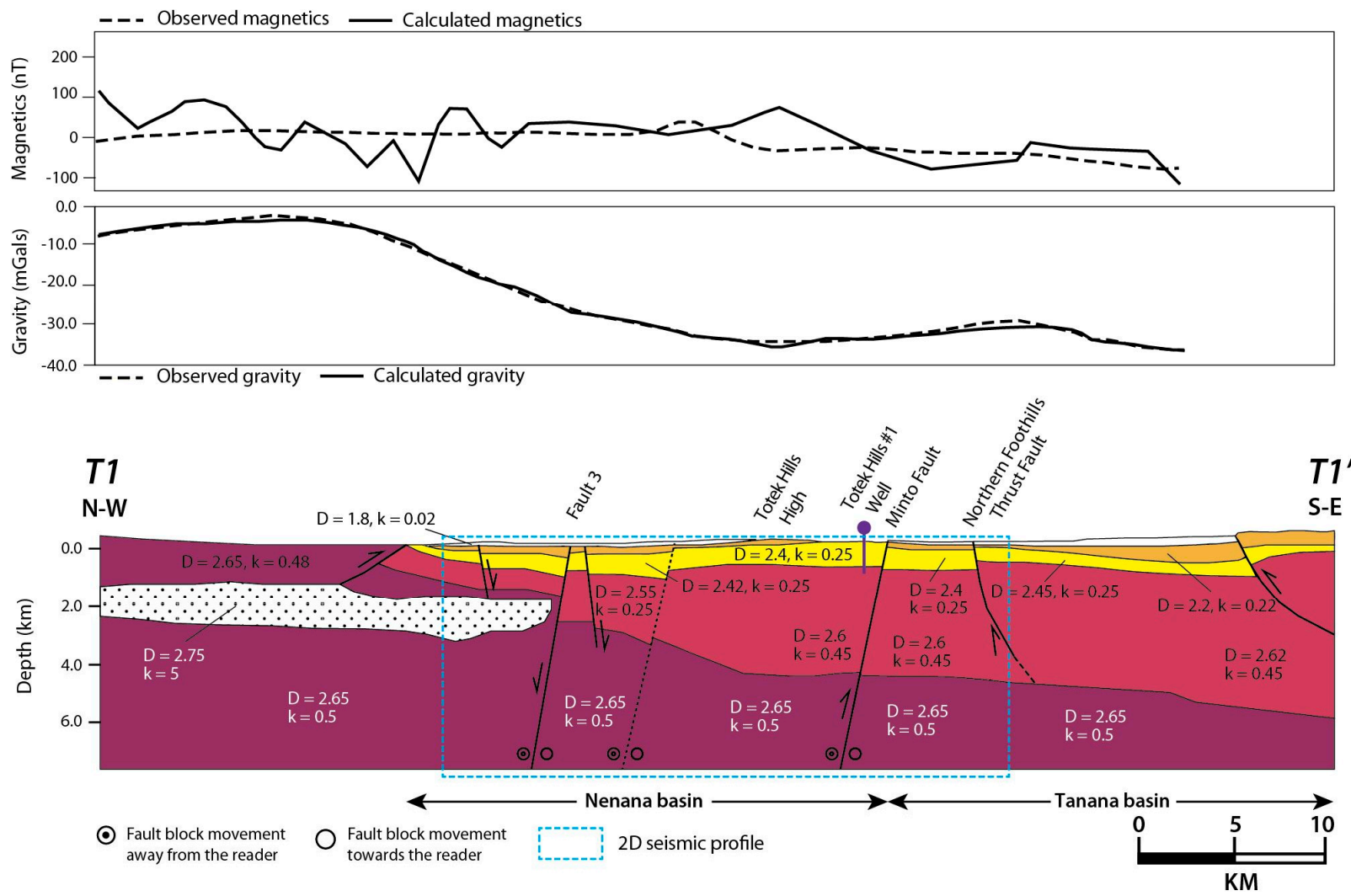

(A)

Figure A1. Cont. 

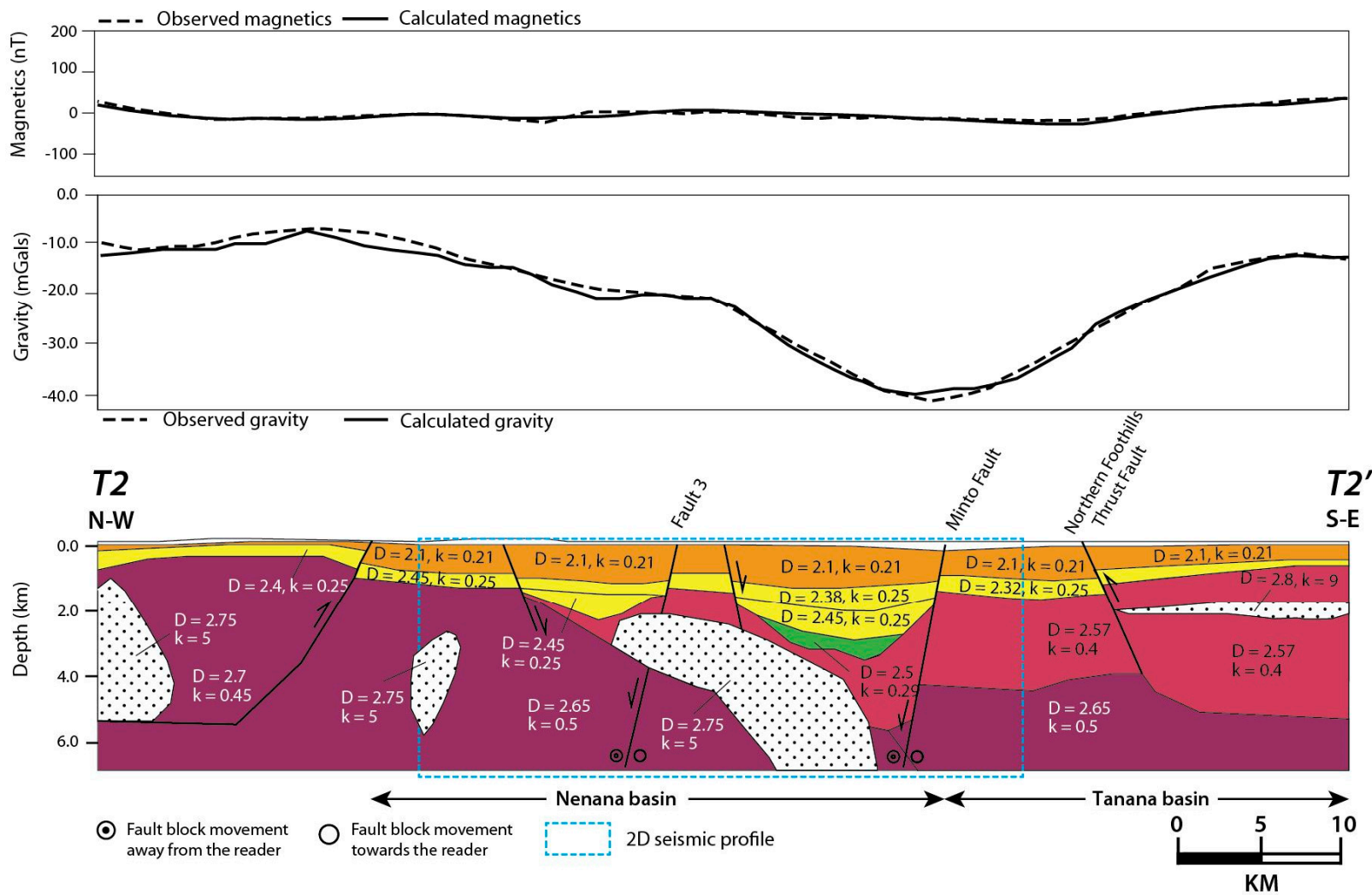

(B)
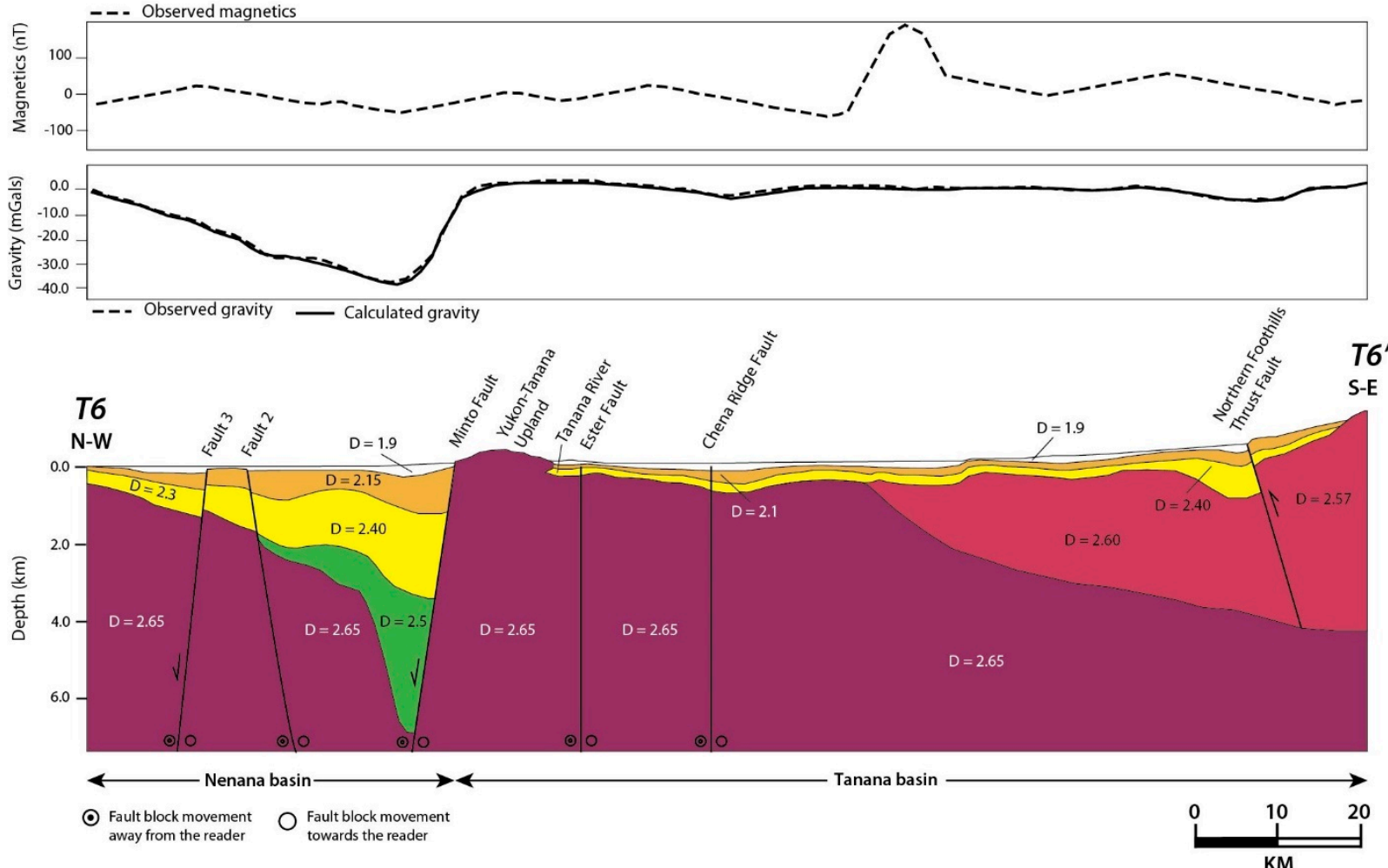

(C)

Figure A1. Cont. 

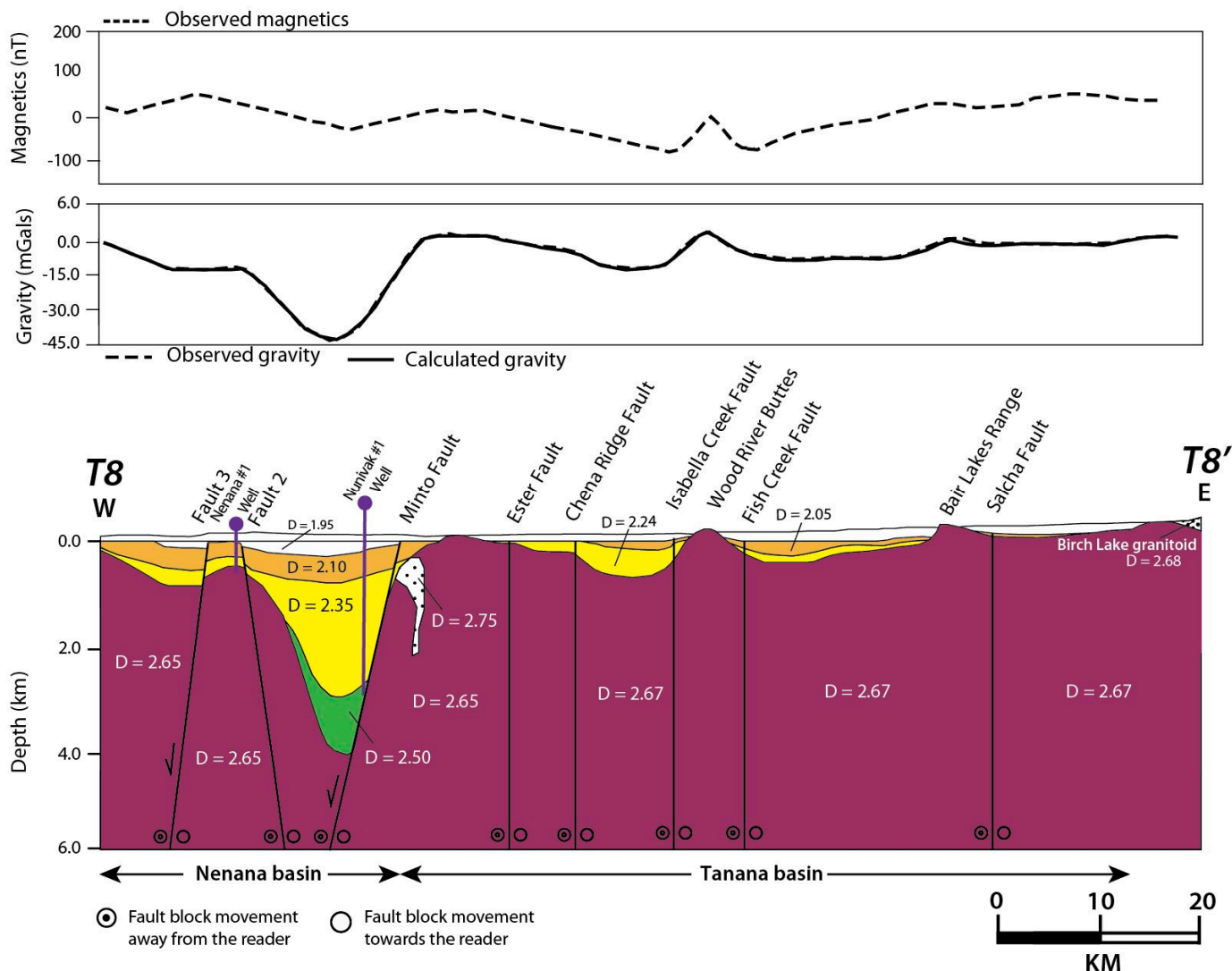

(D)
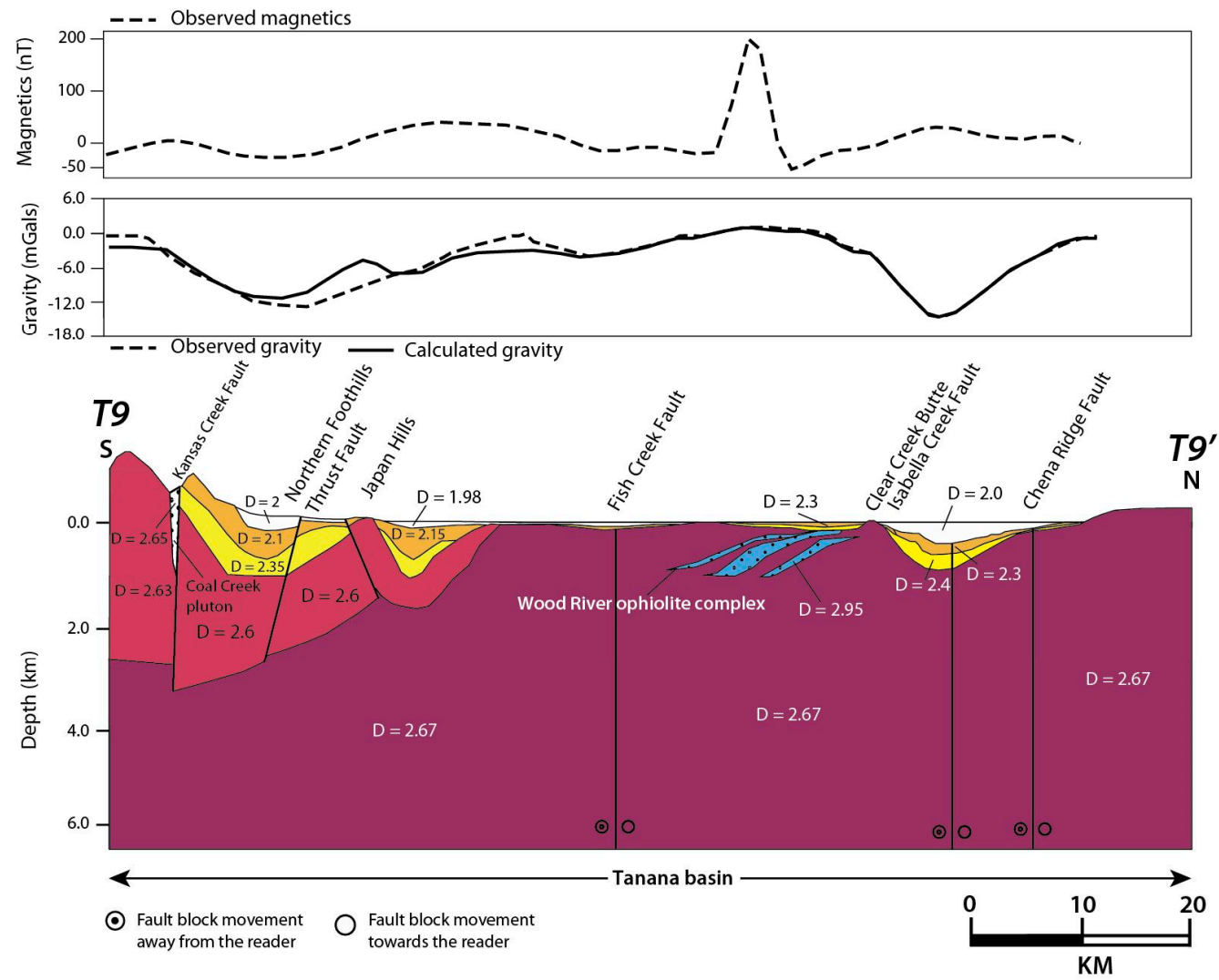

(E)

Figure A1. (A) Upper crustal model along Profile T1. (B) Upper crustal model along Profile T2. (C) Upper crustal model along Profile T6. (D) Upper crustal model along Profile T8. (E) Upper crustal model along Profile T9. 


\section{References}

1. Talwani, P. Unified model for intraplate earthquakes. In Intraplate Earthquakes; Amsterdam University Press: Amsterdam, The Netherlands, 2014; pp. 275-302.

2. Gangopadhyay, A.; Talwani, P. Two-dimensional numerical modeling suggests preferred geometry of intersecting seismogenic faults. In Continental Intraplate Earthquakes: Science, Hazard, and Policy Issues; Stein, S., Mazzotti, S., Eds.; Geological Society of America: Boulder, CO, USA, 2007; pp. 87-99. [CrossRef]

3. Hurd, O.; Zoback, M.D. Intraplate earthquakes, regional stress and fault mechanics in the Central and Eastern, U.S. and Southeastern Canada. Tectonophysics 2012, 581, 182-192. [CrossRef]

4. Page, R.A.; Biswas, N.N.; Lahr, J.C.; Pulpan, H.; Zoback, M.D. Seismicity of Continental Alaska; Geological Society of America: Denver, CO, USA, 1991; pp. 47-68.

5. Fletcher, H. Crustal Deformation in Alaska Measured Using the Global Positioning System. Ph.D. Thesis, University of Alaska Fairbanks, Fairbanks, AK, USA, 2002.

6. $\quad$ Eberhart-Phillips, D.; Christensen, D.H.; Brocher, T.M.; Hansen, R.; Ruppert, N.A.; Haeussler, P.J.; Abers, G.A. Imaging the transition from Aleutian subduction to Yakutat collision in central Alaska, with local earthquakes and active source data. J. Geophys. Res. Space Phys. 2006, 111. [CrossRef]

7. Bemis, S.P. Neotectonic Framework of the North-Central Alaska Range Foothills. Master's Thesis, University of Alaska, Fairbanks, AK, USA, 2004.

8. Koehler, R.D. Quaternary Faults and Folds (QFF). 2013; Volume 3. Available online: http:/ /maps.dggs.alaska.gov/qff/ (accessed on 13 October 2013). [CrossRef]

9. Frohman, R.A. Identification and Evolution of Tectonic Faults in the Greater Fairbanks Area. Alaska. Master's Thesis, University of Alaska Fairbanks, Fairbanks, AK, USA, December 2014.

10. Tape, C.; Silwal, V.; Ji, C.; Keyson, L.; West, M.E.; Ruppert, N. Transtensional Tectonics of the Minto Flats Fault Zone and Nenana Basin, Central Alaska. Bull. Seism. Soc. Am. 2015, 105, 2081-2100. [CrossRef]

11. Ratchkovski, N.A.; Hansen, R. New constraints on tectonics of Interior Alaska:earthquake locations, source mechanisms, and stress regime. Bull. Seismol. Soc. Am. 2002, 92, 998-1014. [CrossRef]

12. Coney, P.J.; Jones, D.L.; Monger, J.W.H. Cordilleran suspect terranes. Nat. Cell Biol. 1980, 288, 329-333. [CrossRef]

13. Nokleberg, W.J.; Richter, D.H. Origin of narrow terranes and adjacent major terranes occurring along the Denali fault in the Eastern and Central Alaska Range, Alaska. In Special Paper 431: Tectonic Growth of a Collisional Continental Margin: Crustal Evolution of Southern Alaska; Geological Society of America: Boulder, CO, USA, 2007; Volume 431, pp. 129-154. [CrossRef]

14. Till, A.B.; Roeske, S.M.; Bradley, D.C.; Friedman, R.; Layer, P.W. Early Tertiary transtension-related deformation and magnetism along the Tintina fault system, Alaska. Geol. Soc. Am. Spec. Pap. 2007, 434, 233-264.

15. Haeussler, P.J. An Overview of the Neotectonics of Interior Alaska: Far-Field Deformation from the Yakutat Microplate Collision. Geophys. Monogr. Ser. 2013, 179, 83-108. [CrossRef]

16. Bemis, S.P.; Weldon, R.J.; Carver, G.A. Slip partitioning along a continuously curved fault: Quaternary geologic controls on Denali fault system slip partitioning, growth of the Alaska Range, and the tectonics of south-central Alaska. Lithosphere 2015, 7, 235-246. [CrossRef]

17. Eberhard-Phillips, D.; Haeussler, P.J.; Freymueller, J.T.; Frankel, A.D.; Rubin, C.M.; Craw, P.; Ratchkovski, N.A.; Anderson, G.M.; Carver, G.A.; Crone, A.J.; et al. The Denali fault earthquake, Alaska-A large magnitude, slip-partitioned event. Science 2003, 300, 1113-1118. [CrossRef] [PubMed]

18. Matmon, A.; Schwartz, D.P.; Haeussler, P.J.; Finkel, R.; Lienkaemper, J.J.; Stenner, H.D.; Dawson, T.E. Denali fault slip rates and Holocene-late Pelistocene kinematics of central Alaska. Geology 2006, 34, 645-648. [CrossRef]

19. Dixit, N.; Hanks, C.; Rizzo, A.; McCarthy, P.; Coakley, B. Cenozoic tectonic and thermal history of the Nenana basin, central interior Alaska: New constrains from seismic reflection data, fracture history, and apatite fission-track analyses. Can. J. Earth Sci. 2017, 54, 766-784. [CrossRef]

20. Barnes, D.F. Gravity low at Minto Flats, Alaska. In Short Papers in the Geologic and Hydrologic Sciences; U.S. Geological Survey: Fairbanks, AK, USA, 1961; pp. 254-257.

21. Kirschner, C.E.; Plafker, G. Interior basins of Alaska. In The Geology of Alaska; Geological Society of America: Boulder, CO, USA, 1994; pp. 469-493.

22. Van Kooten, G.K.; Richter, M.; Zippi, P.A. Alaska's Interior rift basins: A new frontier for discovery. Oil Gas J. 2012, 110, 48-57.

23. Cross, R.S.; Freymueller, J.T. Evidence for and implications of a Bering plate based on geodetic measurements from the Aleutians and western Alaska. J. Geophys. Res. Space Phys. 2008, 113. [CrossRef]

24. Bemis, S.P.; Wallace, W.K.; Ridgway, K.D.; Trop, J.M.; Glen, J.M.; O’Neill, J.M. Neotectonic framework of the north-central Alaska Range foothills. In Special Paper 431: Tectonic Growth of a Collisional Continental Margin: Crustal Evolution of Southern Alaska; Geological Society of America: Boulder, CO, USA, 2007; Volume 431, pp. 549-572.

25. Lesh, M.E.; Ridgway, K.D.; Trop, J.M.; Glen, J.M.; O’Neill, J.M. Geomorphic evidence of active transpressional deformation in the Tanana foreland basin, south-central Alaska. In Special Paper 431: Tectonic Growth of a Collisional Continental Margin: Crustal Evolution of Southern Alaska; Geological Society of America: Boulder, CO, USA, 2007; Volume 431, pp. 573-592. 
26. Ridgway, K.D.; Thoms, E.E.; Layer, P.W.; Lesh, M.E.; White, J.M.; Smith, S.V. Neogene transpressional foreland basin development on the north side of the central Alaska Range, Usibelli Group and Nenana Gravel, Tanana basin. In Special Paper 431: Tectonic Growth of a Collisional Continental Margin: Crustal Evolution of Southern Alaska; Geological Society of America: Denver, CO, USA, 2007; Volume 431, pp. 507-547.

27. Wahrhaftig, C.; Wolfe, J.; Leopold, E.; Lanphere, M. The coal-bearing group in the Nenana coal field, Alaska. In The CoalBearing Group in the Nenana Coal Field, Alaska; US Government Printing Office: Washington, DC, USA, 1969; Volume 1274, pp. D1-D30. [CrossRef]

28. Wilson, F.H. Geologic Map of Central (Interior) Alaska; U.S. Geological Survey Open-File Report 98-133-A, 62, 3 Sheets; U.S. Geological Survey: Reston, VA, USA, 1998.

29. Dixit, N.; Tomsich, C.S. Apatite Fission Track, Magnetic Susceptibility, and Vitrinite Reflectance Analyses on Cuttings from the Nunivak \#1 and Nenana \#1 Wells; Alaska Division of Geological and Geophysical Surveys Geologic Materials Center: Fairbanks, AK, USA, 2014; Volume 422, p. 1. [CrossRef]

30. Grantz, A.; More, T.E.; Roeske, S. Gulf of Alaska to Arctic Ocean; Geological Society of America: Denver, CO, USA, 1991.

31. Fuis, G.S. West margin of North America-synthesis of recent seismic transects. Tectonophysics 1998, 288, 265-292. [CrossRef]

32. Saltus, R.; Hudson, T.; Wilson, F. The geophysical character of southern Alaska-Implications for crustal evolution. In Special Paper 431: Tectonic Growth of a Collisional Continental Margin: Crustal Evolution of Southern Alaska; Geological Society of America: Denver, CO, USA, 2007; Volume 431, pp. 1-20.

33. Doyon Limited. Alaska Onshore Rift Basins, Nenana and Yukon Flats. Available online: http://doyonoil.com/Content/pdfs/ NenanaBasin3DSeismic.pdf (accessed on 12 April 2015).

34. Veenstra, E.; Christensen, D.H.; Abers, G.A.; Ferris, A. Crustal thickness variation in south-central Alaska. Geology 2006, 34, 781-784. [CrossRef]

35. Brennan, P.R.K.; Gilbert, H.; Ridgway, K.D. Crustal structure across the central Alaska Range: Anatomy of a Mesozoic collisional zone. Geochem. Geophys. Geosyst. 2011, 12. [CrossRef]

36. Plouff, D. Preliminary Documentation for a FORTRAN Program to Compute Gravity Terrain Corrections Based on Topography Digitalized on a Geographic Grid; U.S. Geological Survey: Reston, VA, USA, 1977; p. 45. Available online: https://pubs.usgs.gov/of/1977/053 5/report.pdf (accessed on 15 January 2021).

37. Simpson, R.W.; Jachens, R.C.; Blakely, R.J.; Saltus, R.W. A new isostatic residual gravity map of the conterminous United States with a discussion on the significance of isostatic residual anomalies. J. Geophys. Res. Space Phys. 1986, 91, 8348-8372. [CrossRef]

38. Golden Software. Available online: http://www.goldensoftware.com/products/voxler (accessed on 14 April 2015).

39. Meyer, J.F., Jr. Total Intensity Magnetic Anomaly Map of the Nenana Basin, Alaska; Division of Natural Resources Oil and Gas Conservation Commission: Denver, CO, USA, 2018.

40. Veach, N.J. Aeromagnetic Map, Southeastern Part of Fairbanks Quadrangle, Alaska; 1 Sheet, Scale 1:250,000; Alaska Division of Geological \& Geophysical Surveys: Fairbanks, AK, USA, 1973; Volume 5. [CrossRef]

41. Talwani, M.; Worzel, J.L.; Landisman, M. Rapid Gravity Computations for two-dimensional bodies with application to the Mendocine Submarine Fracture Zone. J. Geophys. Res. 1959, 64, 49-61. [CrossRef]

42. Talwani, M.; Heirtzler, J.R. Computation of Magnetic Anomalies Caused by Two-Dimensional Structures of Arbitrary Shape, Computers in the Mineral Industries, Part 1; Stanford University: Stanford, CA, USA, 1964; Volume 9, pp. 464-480.

43. Won, I.J.; Bevis, M. Computing the gravitational and magnetic anomalies due to a polygon: Algorithms and Fortran subroutines. Geophysics 1987, 52, 232-238. [CrossRef]

44. Hanks, C.; Holdmann, G. (Eds.) Using Modeling to Assess $\mathrm{CO}_{2}$ Sequestration, Engineering, Environmental and Economic Issues Related to a Proposed Coal-to-Liquids Plant in Interior Alaska. Available online: https://acep.uaf.edu/media/98300/FA9550-11 -1-0006_Final-Report_reduced-PERMISSION-TO-PUBLISH.pdf (accessed on 15 January 2021).

45. Thoms, E.E. Late Cenozoic Unroofing Sequence and Foreland Basin Development of the Central Alaska Range: Implications from the Nenana Gravel. Master's Thesis, University of Alaska, Fairbanks, AK, USA, May 2000.

46. Saltus, R.W.; Blakely, R.J. Unique geologic insights from "non-unique" gravity and magnetic interpretation. GSA Today 2011, 21, 4-10. [CrossRef]

47. Andreasen, G.; Wahraftig, C.; Zietz, I. Aeromagnetic Reconnaissance of the East-Central Tanana Lowland, Alaska; U.S. Geological Survey: Reston, VA, USA, 1964. [CrossRef]

48. Frost, G.M.; Barnes, D.F.; Stanley, R.G. Geologic and Isostatic Gravity Map of the Nenana Basin Area, Central Alaska; 2 Sheets, Scale 1:250,000; U.S. Geological Survey: Reston, VA, USA, 2002; Volume 16, p. 2543.

49. Péwé, T.L.; Wahrhaftig, C.; Weber, F.R. Geologic Map of the Fairbanks Quadrangle, Alaska; U.S. Geological Survey Miscellaneous Geologic Investigations Map; 1966; Volume 455, p. 5, Sheet 1, Scale 1:250,000. Available online: https://pubs.usgs.gov/imap/i2 $543 /$ (accessed on 15 January 2021).

50. Dusel-Bacon, C.; Harris, A.G. New Occurrences of Late Paleozoic and Triassic Fossils from the Seventymile and Yukon-Tanana Terranes, East-Central Alaska, with Comments on Previously Published Occurrences in the Same Area; Galloway, J.P., Ed.; U.S. Geological Survey: Reston, VA, USA, 2003; Volume 1678, pp. 5-30.

51. Dusel-Bacon, C.; Till, A.B. Geologic studies in Alaska by the U.S. Geological Survey. Bull. U.S. Geol. Surv. 1993, $2068,250$.

52. Roe, J.T.; Stone, D.B. Paleomagnetism of the Fairbanks basalts, Interior Alaska. In Short Notes on Alaskan Geology 1993; Alaska Division of Geological \& Geophysical Surveys: Fairbanks, AK, USA, 2014; Volume 113, pp. 61-69. 
53. Foster, H.L.; Keith, T.E.; Menzie, W.D.; Plafker, G.; Berg, H.C. Geology of the Yukon-Tanana Area of East-Central Alaska; The Geology of Alaska, Geological Society of America: Menlo Park, CA, USA, 1994; pp. 205-240.

54. Hansen, V.L.; Dusel-Bacon, C. Structural and kinematic evolution of the Yukon-Tanana upland tectonites, east-central Alaska: A record of late Paleozoic to Mesozoic crustal assembly. Geol. Soc. Am. Bull. 1998, 110, 211-230. [CrossRef]

55. Werdon, M.B.; RJ Szumigala, D.J. Bedrock Geologic Map of the Eagle A-2 Quadrangle, Fortymile Mining District, Alaska: Alaska Division of Geological \& Geophysical Surveys Preliminary Interpretive Report 2001-3B, 1 Sheet, Scale 1:63,360; Alaska Division of Geological \& Geophysical Surveys: Fairbanks, AK, USA, 2001.

56. Ridgway, K.D.; Trop, J.M.; Nokleberg, W.J.; Davidson, C.M.; Eastham, K.R. Mesozoic and Cenozoic tectonics of the eastern and central Alaska Range: Progressive basin development and deformation in a suture zone. Geol. Soc. Am. Bull. 2002, 114, 1480-1504. [CrossRef]

57. DeCelles, G.; Giles, K.N. Foreland basin systems. Basin Res. 1996, 8, 105-123. [CrossRef]

58. Wu, J.E.; McClay, K.; Whitehouse, P.; Dooley, T. 4D analogue modelling of transtensional pull-apart basins. Mar. Pet. Geol. 2009, 26, 1608-1623. [CrossRef] 